\title{
Cholecystokinin-like Peptide Is a Modulator of a Crustacean Central Pattern Generator
}

\author{
Gina G. Turrigiano and Allen I. Selverston \\ Department of Biology, University of California at San Diego, La Jolla, California 92093
}

The presence, release, and physiological effects of a cholecystokinin(CCK)-like peptide within the stomatogastric ganglion (STG) of the lobster, Panulirus interruptus, are described. Indirect immunofluorescence with 2 antisera raised against CCK8 was used to determine the distribution of CCKlike immunoreactivity (CCKLI) in the stomatogastric nervous system. CCKLI was demonstrated in the input nerve and the neuropil of the STG and in neuropil and somata in the commissural ganglia (CGs), brain, and eyestalks. None of the somata within the STG displayed CCKLI. The cross-reactivities of the CCK antisera with several peptides were determined using either a radioimmunoassay or an immunoblot assay; the antisera recognized peptides homologous to CCK but did not cross-react significantly with several unrelated peptides.

The STG contains 2 central pattern generators (CPGs), the pyloric and the gastric mill CPGs. Bath application of CCK8 to the STG had modulatory effects on both CPGs, which were dose dependent and reversible. CCK increased the spike frequencies and number of spikes per burst of the pyloric rhythm but had little effect on the period. CCK increased the period of the gastric rhythm and produced changes in the spike frequencies, burst lengths, and phases of gastric units. High concentrations of peptide were needed to produce these effects $\left(10^{-6}\right.$ to $\left.10^{-4} \mathrm{M}\right)$.

Finally, stimulation of the stomatogastric nerve (stn), which contains fibers immunoreactive to $\mathrm{CCK}$, produced calciumdependent release of CCK molar equivalents (CCKE) into the STG. The stn was electrically stimulated and the superfusate around the ganglion was collected and assayed for CCKE using a radioimmunoassay. Stimulation produced the release of $37.1 \pm 7.1 \mathrm{fmol}$ (mean \pm SEM), compared to 13.7 $\pm 4.9 \mathrm{fmol}$ for unstimulated controls and $4.9 \pm 2.9 \mathrm{fmol}$ in the absence of calcium. These data suggest that a CCK-like peptide is an endogenous modulator of the stomatogastric ganglion of $\boldsymbol{P}$. interruptus.

In the last several decades there has been a great proliferation in the number of peptides that have been localized to specific neurons and neural circuits. Many of these peptides are thought to act as neurotransmitters or as neuromodulators, but their

\footnotetext{
Received Oct. 7, 1988; revised Jan. 5, 1989; accepted Jan. 10, 1989.

We wish to thank Lynn Ogden for her expert technical assistance, and Eve Marder, Ron Harris-Warrick, and Sacha Nelson for their critical reading of this manuscript. This work was supported by NIH grants NS 09322 and NS 25916, and NSF grant BNS-8518238.

Correspondence should be addressed to Gina G. Turrigiano at the above address.

Copyright $@ 1989$ Society for Neuroscience $0270-6474 / 89 / 072486-16 \$ 02.00 / 0$
}

physiological functions often remain unclear. The stomatogastric ganglion (STG) of decapod crustacea has proven to be a useful model system for assessing the effects of neuromodulators on neural circuits (for reviews, see Marder, 1987; Harris-Warrick, 1988). This small ganglion contains 2 well-defined central pattern generators (CPGs), the pyloric and the gastric mill CPGs, which control rhythmic movements of the digestive tract. All of the neurons in these 2 circuits have been identified and their interconnections determined, and the mechanisms by which they produce patterned motor outputs are now largely understood (Mulloney and Selverston, 1974a, b; Selverston and Miller, 1980; Eisen and Marder, 1982; Miller and Selverston, 1982a, b).

Although these CPGs produce stereotyped outputs in vitro, the in vivo patterns are quite variable (Rezer and Moulins, 1983; Heinzel, 1988a); recently workers have concentrated on determining the basis of this flexibility. There are several levels of control over the behavior of the STG, including cycle-by-cycle sensory feedback and longer-term hormonal and modulatory influences. A large number of putative modulators are present in the input fibers to this ganglion, and bath application of several peptides and amines can profoundly alter the motor programs of its component CPGs. Such modulators include the monoamines (Beltz et al., 1984; Marder and Eisen, 1984; Flamm and Harris-Warrick, 1986a,b) and the neuropeptides FMRFamide, proctolin, and red pigment concentrating hormone (RPCH) (Hooper and Marder, 1984, 1987; Marder et al., 1986; Heinzel and Selverston, 1988; Nusbaum and Marder, 1988). Each of these modulators is thought to act on a unique constellation of cellular and synaptic properties of these CPGs to cause them to produce different stable patterns. In this paper we present evidence that a cholecystokinin (CCK)-like peptide is present in the lobster STG and acts as a modulator of the circuits of the STG.

CCK is one of a family of peptides, including the gastrins and caerulein peptide, which share a terminal amino acid sequence. Originally identified in mammalian gut tissuc, thcse peptides are thought to control several aspects of vertebrate gut function, including the induction of gut motility and the signaling of satiety (for a review, see Dockray, 1978; Smith and Gibbs, 1985; Baile and Della-Fera, 1985). CCK has subsequently been demonstrated in the CNS of many vertebrates (Dockray, 1976; Marley et al., 1984; Kritzer et al., 1987) and has been shown to affect the excitability of some classes of CNS neurons (Skirboll et al., 1981; Brooks and Kelly, 1985). In recent years, antibodies specific for the terminal sequence of CCK have been used to identify CCK-like peptides in a number of invertebrates, including arthropods (Larson and Vigna, 1983a, b). A CCK-like peptide from the brain of Calliphora vomitoria has been char- 
acterized immunohistochemically and biochemically (Dockray et al., 1981; Duve and Thorp, 1981). CCK-like immunoreactivity (CCKLI) has been demonstrated in the gut epithelial cells of the crab, Cancer magister (Scalise et al., 1984), and more recently in the stomach and in the eyestalk neurohemal organ of the prawn, Palaemon serratus (Favrel et al., 1987). Few invertebrate CCK-like peptides have been sequenced to date. The peptide leucosulfakinin has been isolated from the head of the cockroach, Leucophaea maderae; it contains a sequence homologous to the terminal sequence of CCK8 and can increase the size and frequency of spontaneous hindgut contractions (Nachman et al., 1986). Recently several CCK-like peptides have been cloned from Drosophila and termed drosulfakinin (Nichols et al., 1988), and there is preliminary evidence that these peptides can inhibit ingestion in blowflys (R. Nichols, personal communication). These studies suggest that invertebrate CCK-like peptides have analogous physiological roles to their vertebrate homologs, making CCK-like peptides excellent candidate modulators of the crustacean STG.

In this paper we demonstrate that a CCK-like peptide is present in the stomatogastric nervous system of the lobster, Panulirus interruptus, and that it can be released into the STG. Further, we show that the activity of the pyloric and gastric mill CPGs can be modified by bath application of CCK. We suggest that an endogenous CCK-like peptide acts as a neuromodulator of the circuits in the STG, thus establishing a direct neural role in the control of gut function for an invertebrate CCK-like peptide.

A preliminary report of these results has appeared (Turrigiano and Selverston, 1987).

\section{Materials and Methods \\ Animals}

Specimens of the California spiny lobster, Panulirus interruptus, were obtained locally and kept without food in a running seawater aquarium at $13-15^{\circ} \mathrm{C}$ until use. Specimens of both sexes were used.

\section{Peptides and reagents}

We obtained reagents from the following sources. CCK8, CCK8SO gastrin, caerulein peptide, proctolin, met- and leu-enkephalin, and activated charcoal were obtained from Sigma. Ultrapure-grade phenylmethylsulfonyl fluoride (PMSF) was obtained from Boehringer Mannheim Biochemicals. Diaminobenzidine was obtained from Organon Teiknika Corp. Nitrocellulose paper (type tm-nc4-1515) was obtained from Hoefer Scientific Instruments. $\mathrm{CCK}_{8 \mathrm{SO}_{4}}{ }^{125}$, labeled on the $n$-terminal aspartate by the Bolton Hunter technique and purified to $>90 \%$ by high-performance liquid chromatography, was obtained from Amersham.

\section{Antisera}

Commercially obtained antisera. Rabbit $\mathrm{CCK} /$ gastrin antiserum raised against CCK 8 conjugated to keyhole limpet hemocyanin (antiserum A) was obtained from Incstar. The cross-reactivity of the antiserum with a number of peptides was assayed using an immunoblotting technique. One microgram of each of the following was dried onto nitrocellulose paper: $\mathrm{CCK} 8, \mathrm{CCK}_{8 \mathrm{SO}_{4}}$, gastrin 17, caerulein peptide, proctolin, FMRFamide, substance $P$, leu-enkephalin, and met-enkephalin. The paper was allowed to dry, incubated in $10 \%$ horse serum for $2 \mathrm{hr}$, and then incubated with antiserum $A$ at a dilution of 1:200 for $2 \mathrm{hr}$. The paper was washed, incubated with goat anti-rabbit conjugated to HRP, washed, and developed in diaminobenzidine $(1 \mathrm{mg} / 20 \mathrm{ml} 20 \mathrm{~mm}$ Tris buffer, pH 7.0, to which was added $20 \mu \mathrm{l}$ of $30 \% \mathrm{H}_{2} \mathrm{O}_{2}$ ) for $10 \mathrm{~min}$. The paper was washed, dried, and photographed. This assay was sensitive to $1 \mathrm{ng}$ of $\mathrm{CCK} 8, \mathrm{CCK} 8 \mathrm{SO}_{4}$, and caerulein peptide, and somewhat less sensitive to gastrin 17 , all of which share a terminal amino acid sequence. No reaction was observed for the other peptides. Of the several types of nitrocellulose paper tested, only type tm-nc4-1515 was able to bind CCK.

Rabbit CCK/gastrin antiserum raised against CCK8 conjugated to bovine serum albumen (antiserum B) was obtained from Amersham. The specificity of this antiserum was tested in a radioimmunoassay (see below). Goat anti-rabbit IgG conjugated to rhodamine was obtained from Jackson, and goat anti-rabbit conjugated to HRP was obtained from Cappel.

Production of antiserum. CCK/gastrin antiserum $\mathrm{C}$ was obtained from a New Zealand White rabbit injected with a gluteraldehyde-cross-linked CCK8-thyroglobulin conjugate made using a modified version of the methods of O'Donahue et al. (1984). One milligram of CCK8, $2.86 \mathrm{mg}$ of thyroglobulin, and approximately $30,000 \mathrm{CPM}$ of CCKI ${ }^{125}$ were added

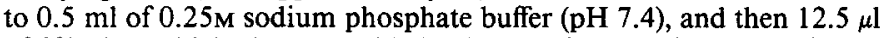
of $8 \%$ glutaraldehyde were added. The solution was incubated for 30 min and then dialyzed against $\mathrm{dH}_{2} \mathrm{O}$ for $24 \mathrm{hr}$ at $4^{\circ} \mathrm{C}$. The labeled CCK was added in order to estimate the efficiency of the conjugation procedure; approximately $65 \%$ of the $\mathrm{CCKI}^{25}$ was incorporated into the conjugate. The antigen was emulsified in an equal volume of Freund's adjuvant, and $2 \mathrm{ml}$ were injected into the muscles along the spinal cord. The rabbit was given boosts of approximately the same amount of antigen every 4 weeks and was bled $10 \mathrm{~d}$ after injection. The specificity of antiserum $\mathrm{C}$ was tested in radioimmunoassay (see below).

\section{Immunocytochemistry}

Tissues were processed as whole mounts for immunocytochemistry using indirect immunofluorescence in a modification of the procedure of Beltz and Kravitz.(1983). Dissections were carried out in chilled $\mathrm{Pa}$ nulirus saline (saline composition in mM: $\mathrm{NaCl}, 479 ; \mathrm{KCl}, 12.7 ; \mathrm{CaCl}_{2}$, 13.7; $\mathrm{MgSO}_{4}, 10.0 ; \mathrm{Na}_{2} \mathrm{SO}_{4}, 3.9$; glucose, 2.0 ; Hepes, 5.0; Tes, 5.0; pH, 7.4). The complete stomatogastric nervous system (Fig. 1) was removed in all cases; in some experiments the brain and optic nerves, the thoracic ganglia, and the tail ganglia were also removed. All ganglia were desheathed. For some preparations the lobsters were injected with $15 \mathrm{mg} /$ $\mathrm{kg}$ of colchicine in physiological saline $2 \mathrm{~d}$ prior to dissection; this procedure improved the ability to stain somata.

Antiserum A. The tissue was fixed for $16-20 \mathrm{hr}$ in $4 \%$ paraformaldehyde in $0.1 \mathrm{~m}$ phosphate buffer with $0.9 \% \mathrm{NaCl}$ at $\mathrm{pH} 7.4$ (PBS). The tissue was washed for $6 \mathrm{hr}$ in PBS with 5\% normal goat serum (NGS) and $1 \%$ Triton X-100 (TX) and then incubated for $16-20 \mathrm{hr}$ in antiserum A diluted 1:200 (PBS, 0.3\% TX, 5\% NGS, $3.3 \mathrm{mg} / \mathrm{ml} \mathrm{BSA}$ ). The tissue was washed for $6 \mathrm{hr}$ (PBS, 5\% NGS) and then incubated for 16-20 hr with goat anti-rabbit IgG conjugated to rhodamine, diluted 1:200 (PBS, $5 \%$ NGS). The tissue was washed in PBS, cleared and mounted in buffered glycerol, and visualized with a Zeiss fluorescent microscope using rhodamine filters.

The specificity of the staining produced by antiserum A was determined by a preabsorption control. The antiserum was incubated overnight with $10^{-6} \mathrm{M} \mathrm{CCK}, 10^{-3} \mathrm{M}$ FMRFamide, or $10^{-3} \mathrm{M}$ proctolin prior to incubation with the tissue.

Antiserum $C$. The staining procedure used was identical to that used for antiserum A except that the antiserum was diluted 1:200 in PBS, $0.3 \% \mathrm{TX}, 5 \% \mathrm{NGS}$, and $3.3 \mathrm{mg} / \mathrm{ml}$ bovine thyroglobulin. A preabsorption control was performed as for antiserum $\mathrm{A}$.

\section{Radioimmunoassay}

Antiserum B. Antiserum B was diluted 1:400 into a radioimmunoassay (RIA) buffer of $50 \mathrm{~mm}$ sodium phosphate, $0.2 \%$ gelatin, and $10 \mathrm{~mm}$ EDTA. One hundred microliters of the diluted antiserum, $100 \mu \mathrm{l}$ of $\mathrm{CCKJ}^{125}$ diluted in assay buffer so as to contain 6000-10,000 CPM/100 $\mu \mathrm{l}$, and either a CCK standard or a sample diluted to $600 \mu \mathrm{l}$ in assay buffer, were added to a microcentrifuge tube, vortexed, and incubated overnight at $4^{\circ} \mathrm{C}$. The entire tube was counted in a Tracor Analytic gamma counter. Goat anti-rabbit IgG $50 \mu \mathrm{l}$, diluted $1: 1000$ was added to each tube and allowed to incubate for $20 \mathrm{~min} ; 250 \mu \mathrm{l}$ of dextrancoated charcoal were then added to each tube, the tubes were vortexed and then microfuged for $10 \mathrm{~min}$. The supernatant, $550 \mu \mathrm{l}$, was withdrawn and counted in a Tracor Analytic gamma counter. The percentage of tracer bound by the antiserum was determined by dividing the number of counts in the supernatant by the total number of counts. Blanks (no peptide and no antibody) ran at about $5 \%$, and zeros (no peptide) ran from $45-55 \%$. Unknowns were quantified by determining the amount of CCK8 necessary to produce an equivalent inhibition of binding; values are therefore expressed in terms of CCK molar equivalents (CCKE). 

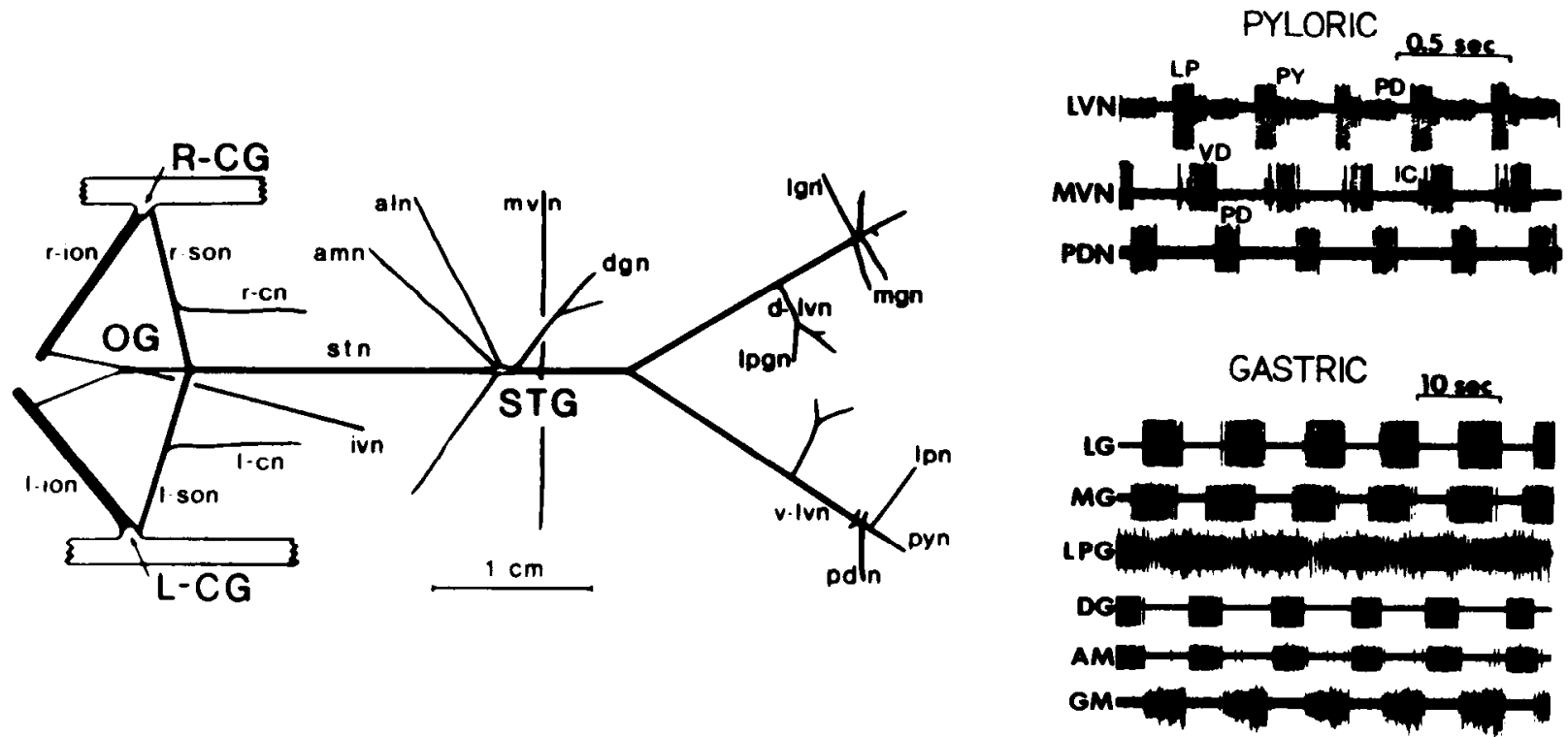

Figure 1. Stomatogastric nervous system. Left, Schematic representation of the combined preparation used in the physiology experiments, which includes the STG, the OG, the paired CGs, and the motor nerves from which the pyloric and gastric activity was recorded. Top right, Extracellular recordings of the pyloric motor activity. Bottom right, Extracellular recordings of the gastric motor activity. Note the difference in time scale between the 2 patterns. See Appendix for list of abbreviations of names of nerves and units.

CCK 8 standards were run in the range of $1-3000 \mathrm{fmol}$; all points were run in duplicate. As little as 5 fmoles could routinely be detected in this assay, and 20-30 fmoles reduced antibody binding by $50 \%$. This antiserum recognizes peptides which share a terminal amino acid sequence with CCK (gastrin and caerulein peptide) equally well, but 5 unrelated peptides (FMRFamide, proctolin, met-enkephelin, substance $\mathrm{P}$, and $\mathrm{RPCH}$ ) produced no inhibition of binding in the range of 13000 fmoles (Fig. 2A).

A new standard curve was run for each experiment. For the release experiment, $20 \mu$ l of Panulirus saline containing PMSF (1:500) were added to each tube in the standard curve; this did not interfere with the assay.

Antiserum $C$. The first bleed of antiserum $C$ was tested in RIA at dilutions of $1: 10,1: 20,1: 50,1: 100$, and 1:200; the assay was performed as above. At a dilution of 1:50 the inhibition of binding curve for CCK 8 was linear between 1 and $50 \mathrm{fmol}$. Up to $10 \mathrm{pmol}$ of FMRFamide, proctolin, RPCH, substance $P$, or met-enkephelin failed to inhibit binding (Fig. $2 B$ ). Later bleeds gave equivalent binding curves at dilutions as low as 1:500.

\section{Physiology}

Dissections were performed in cold physiological saline according to the methods of Mulloney and Selverston (1974a). All experiments were done using the "combined preparation" in which the paired commissural ganglia (CGs) and the esophageal ganglion (OG) are left attached to the STG via the stomatogastric nerve (stn) (Fig. 1). Preparations were pinned out in sylgard-lined petri dishes and superfused with physiological saline of $16-18^{\circ} \mathrm{C}$. In some preparations the STG was reversibly isolated by placing a vaseline well filled with isotonic sucrose around the desheathed stn. A vaseline well was built around the STG so that it could be independently superfused; the composition of the superfusate could be changed by means of a switching port in the inflow tubing. In 5 experiments the temperature of the entire preparation was maintained at $16^{\circ} \mathrm{C}$ by means of a circulating water bath. Unless otherwise noted, the protease inhibitor PMSF was used in all physiological salines, including controls and washes. A stock solution of $30 \mathrm{mg} / \mathrm{ml}$ was made up in ethanol and diluted 1:5000 in Panulirus saline, for a final concentration of $0.006 \mathrm{mg} / \mathrm{ml}$. The STG was superfused with saline plus PMSF for at least $1 \mathrm{hr}$ before control activity was ascertained. At this concentration the only noticeable effect of PMSF was that it occasionally increased the frequency of the gastric rhythm; this effect stabilized within a few minutes. Stock solutions of CCK8SO, were made fresh in $\mathrm{Pa}$ nulirus saline before each experiment and were diluted in saline to the appropriate concentration. The pH of these solutions was 7.4. Standard recording techniques for this preparation were used (Mulloney and Selverston, 1974a). Extracellular recordings were made with stainlesssteel pin electrodes isolated from the bath with vaseline. Intracellular recordings were made using $\mathrm{KCI}$ microelectrodes with resistance of 20-30 MS.

\section{Release experiment}

The combined STG nervous system was dissected as for physiology, and a vaseline well with a capacity of $10 \mu$ was built around the completely desheathed STG. The activities of the STG and the stn were monitored extracellularly. The stn was sucrose blocked, and a bipolar suction electrode was used to stimulate the stn en passant between the sucrose block and the ganglion. The protease inhibitor PMSF was used in the physiological saline at a concentration of $0.06 \mathrm{mg} / \mathrm{ml}$ for these experiments.

Several types of stimulating electrodes and stimulation paradigms were tested for their efficacy in producing release of CCKE: stimulation using a platinum bipolar stimulating electrode placed against the nerve and insulated from the bath with vaseline; stimulation using a bipolar suction electrode; stimulation at $20 \mathrm{~Hz}$ in trains of $500-\mathrm{msec}$ duration delivered every $2 \mathrm{sec}$; and continuous stimulation at $20 \mathrm{~Hz}$. The best technique proved to be continuous stimulation using a suction electrode, and was used for the experiments reported here. At the beginning of each experiment the current was adjusted until 2 criteria were met: (1) recruitment of units in the stn could be observed; and (2) delivery of a short stimulus train at $20 \mathrm{~Hz}$ would activate the pyloric rhythm for several minutes, indicating that the stimulation was effective in releasing modulatory substances into the STG.

Stimulation of the stn for $1 \mathrm{hr}$ was compared in the same experiment to no stimulation and to stimulation in saline in which the calcium had been replaced with magnesium. For each condition, $10 \mu \mathrm{l}$ of saline were added to the well around the STG and were withdrawn $1 \mathrm{hr}$ later and put into a microcentrifuge tube. The well was washed with $10 \mu \mathrm{l}$ of saline which were also added to the tube, and the contents of the tube were flash-frozen and stored at $-70^{\circ} \mathrm{C}$ until assayed for CCKE by radioimmunoassay using antiserum $B$. Assays were performed in the same tube. The order in which the conditions were performed was varied.

For 4 experiments, stimulation in 30-min bouts was interspersed with 30 min control; this was repeated 5 times, for a total of $2.5 \mathrm{hr}$ of cumulative stimulation and $2.5 \mathrm{hr}$ of cumulative control. The superfusate was withdrawn every $30 \mathrm{~min}$ and assayed separately as described above. 


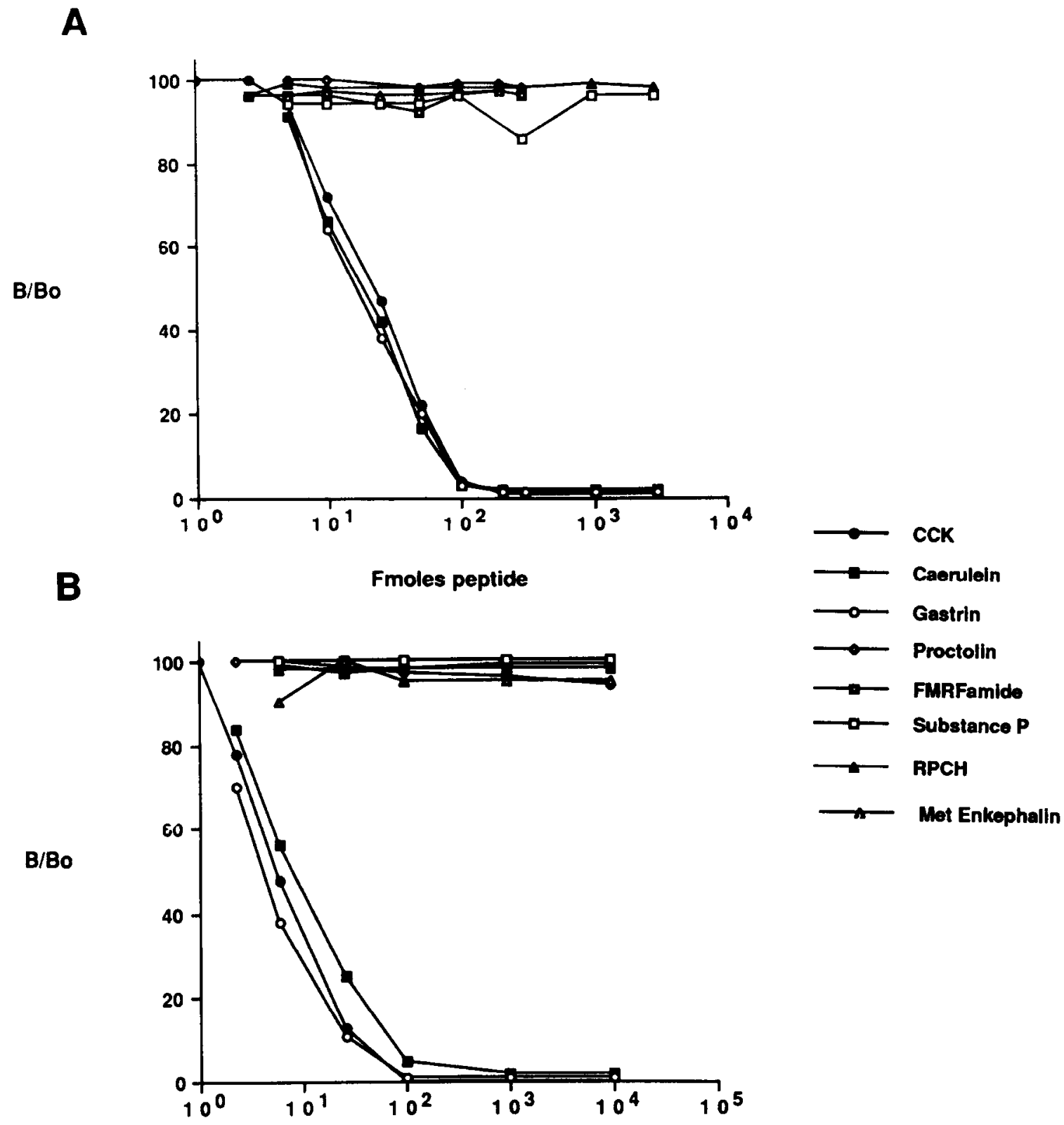

Fmoles peptide

Figure 2. RIA using anti-CCK antisera $\mathrm{B}$ and C. Inhibition of binding of the antisera to CCK8I ${ }^{125}$ by 8 different peptides. $A$, Antiserum B. $B$, Antiserum C. For both antisera, CCK, gastrin, and caerulein peptide inhibited binding about equally, and binding was inhibited completely by about 100 fmoles of peptide. Five structurally unrelated peptides (proctolin, FMRFamide, substance P, RPCH, and met-enkephalin) did not inhibit binding in the range of 5 fmoles to 10 pmoles. $B / B O$, Percentage of tracer bound divided by the percentage bound when there is no competing peptide.

\section{Results}

\section{Immunocytochemistry}

In this section we describe the distribution of CCKLI in the nervous system of Panulirus interruptus. Data were obtained from more than 40 juvenile lobsters (6-8 inches), which were used because antiserum penetrability is better in juveniles than in adults in some crustaceans (Beltz and Kravitz, 1983). Two different antisera directed against CCK8 were used.

The STG of Panulirus interruptus contains approximately 30 somata, which are arranged in a rind above a ball of dense neuropil. When the STG was processed for whole-mount immunocytochemistry, this neuropil displayed CCKLI; both antiserum A (Fig. $3 A$ ) and antiserum $C$ (Fig. $3 B$ ) gave the same result. One or 2 fibers or fiber bundles could be seen entering the STG from the stn (Fig. 3A, arrow) and branching out into the ganglion. The somata within the STG did not display CCKLI Figure $3 B$ shows a side view of the STG in which unstained somata (arrow) can be seen above a core of stained neuropil. None of the motor nerves which exit the ganglion displayed CCKLI.

To test further the specificities of the primary antisera for 

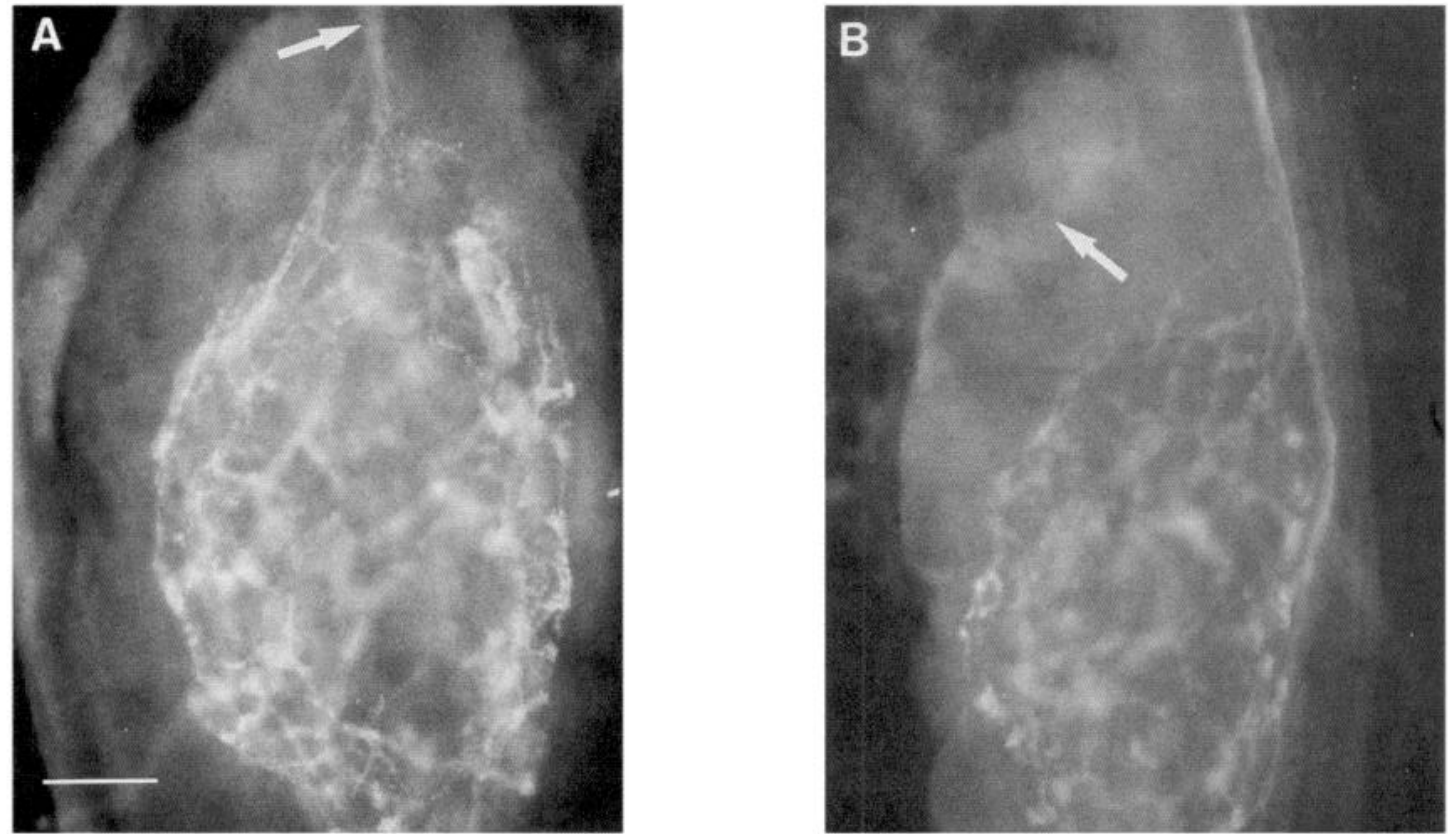

Figure 3. CCKLI in the STG. $A$, Whole mount of the STG stained with antiserum A (1:200 dilution). Fibers can be seen entering the STG from the stn (arrow). Note punctate neuropilar staining. B. Side view of the STG stained with antiserum C (1:200 dilution). The unstained somata (arrow) lie above a core of stained neuropil. Signal is light; background is dark. Scale bar, $100 \mu \mathrm{m}$.

CCK-like peptides, the antisera were preabsorbed with several different peptides prior to incubation with the tissue. Preabsorption with $10^{-5} \mathrm{M}$ CCK 8 completely abolished the staining (Fig. 4A), whereas staining was unaffected by preabsorption with the same concentration of FMRFamide (Fig. $4 B$ ) or proctolin
(Fig. $4 C$ ). Even higher concentrations of these 2 peptides $\left(10^{-3}\right.$ M) did not abolish the staining. These peptides were chosen because they have been shown to be present in the STG neuropil (Marder et al., 1986, 1987).

The STG receives input from higher ganglia through the stn,
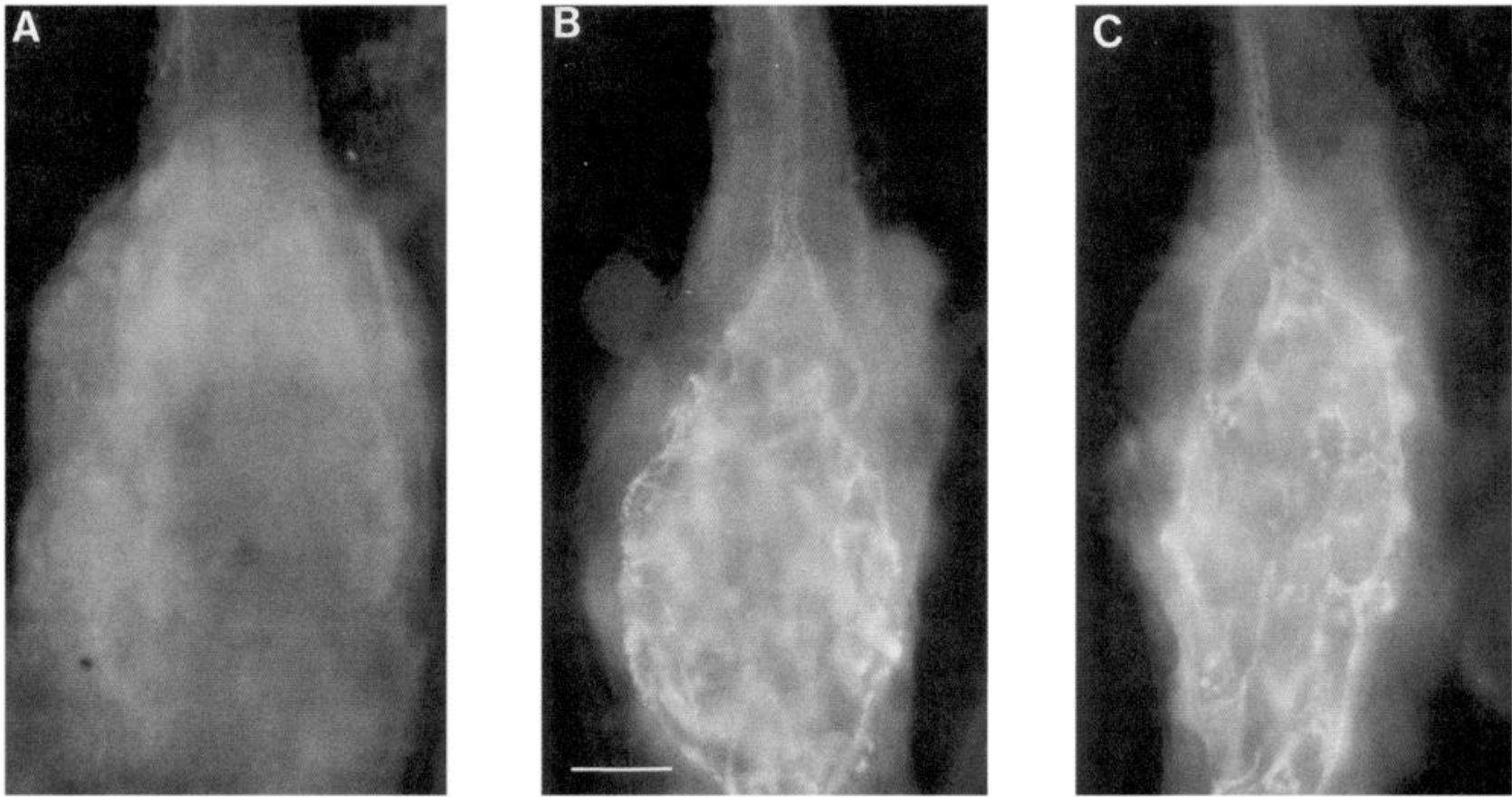

Figure 4. Specificity of antiserum $\mathrm{C}$ for CCK-like peptides. $A$, Whole mount of the STG. Antiserum C was preabsorbed with $10^{-5} \mathrm{M}$ CCK prior to incubation with the tissue; staining was abolished. $B$. Antiserum $C$ was preabsorbed with $10^{-5} \mathrm{M}$ FMRFamide prior to incubation with the tissue. Staining was unaffected. $C$, Antiserum $\mathrm{C}$ was preabsorbed with $10^{-5} \mathrm{M}$ proctolin prior to incubation with the tissue. Staining was unaffected. Scale bar, $100 \mu \mathrm{m}$. 
the sole input nerve to the STG. The presence of stained fibers in the stn and the absence of stained somata in the STG or stained fibers in motor nerves suggested that the somata responsible for the neuropilar staining in the STG reside in one of these input ganglia. Somata which stain for several putative neuromodulators have been observed in the CGs and the OG (Marder et al., 1986, 1987; Goldberg et al., 1988; Nusbaum and Marder, 1988); we therefore examined them for the presence of CCKLI.

One or 2 immunoreactive fibers were observed in each superior esophageal nerve (son), a nerve that connects the stn to the CGs (see Fig. 1 for anatomy). No staining was observed in the $\mathrm{OG}$ or in the ions. Sparse neuropilar staining was observed at the junction of the sons and stn. When animals were pretreated with colchicine, one or 2 large somata and several smaller somata in each paired CG displayed CCKLI (Fig. $5 A$, arrows). Neuropilar staining was observed in the CGs, and stained fibers were observed in the commissural commissures, which project to the brain in one direction and to the abdominal ganglia in the other. Several strongly staining fibers were observed in the optic nerve (Fig. $5 B$ ); these fibers entered the brain and branched out into brightly stained neuropil (Fig. $5 \mathrm{C}$ ). Other stained fibers, somata, and neuropil were also observed in the brain. No staining was observed in the tail ganglia $(n=3)$.

There was some variability in staining from animal to animal. Some structures stained very reliably; staining of others was more labile. Fibers in the stn and neuropil in the STG stained in virtually every preparation (more than 40 overall), as did fibers, neuropil, and somata in the brain and fibers in the optic nerve. Somata in the CGs, on the other hand, stained reliably only if the animal had been pretreated with colchicine, and staining in the sons and at the stn/son junction was observed only when the nerves were desheathed $(n=5)$. It was not possible to follow immunoreactive axons all the way from somata in the CGs or brain to the STG. Figure 6 illustrates and summarizes the CCK-like staining pattern observed in the stomatogastric nervous system of Panulirus interruptus.

\section{Physiology}

The presence of diffuse CCKLI in the neuropil of the STG suggests that a CCK-like peptide plays a physiological role in this ganglion. We therefore bath-applied several CCK analogues to the STG to determine whether they have modulatory effects on the rhythmic motor output of the STG. Preliminary results with human gastrin 17 and unsulfated CCK indicated that they had no detectable effects on the STG, whereas caerulein peptide and $\mathrm{CCK}_{8 \mathrm{SO}_{4}}$ were able to modulate the output of the STG. The effects of caerulein peptide were similar to but somewhat weaker than $\mathrm{CCK}_{8} \mathrm{SO}_{4}$, and so the latter peptide was chosen for further analysis. Data were obtained from 17 adult lobsters.

\section{Pyloric $C P G$}

The pyloric CPG is composed of 13 motoneurons and 1 interneuron which are organized into a circuit that produces a 3-phase rhythm. This rhythm controls the contractions of the pyloric region of the lobster stomach. In the combined in vitro preparation, the pyloric CPG bursts vigorously with a frequency of $1-2 \mathrm{~Hz}$ and with a stereotyped order of firing: anterior burster (AB)/pyloric dilator (PD), lateral pyloric neuron (LP)/inferior cardiac neuron (IC), pylorical neuron (PY)/ventral dilator (VD). This activity is illustrated in Figure $7 A$; the medial ventricular
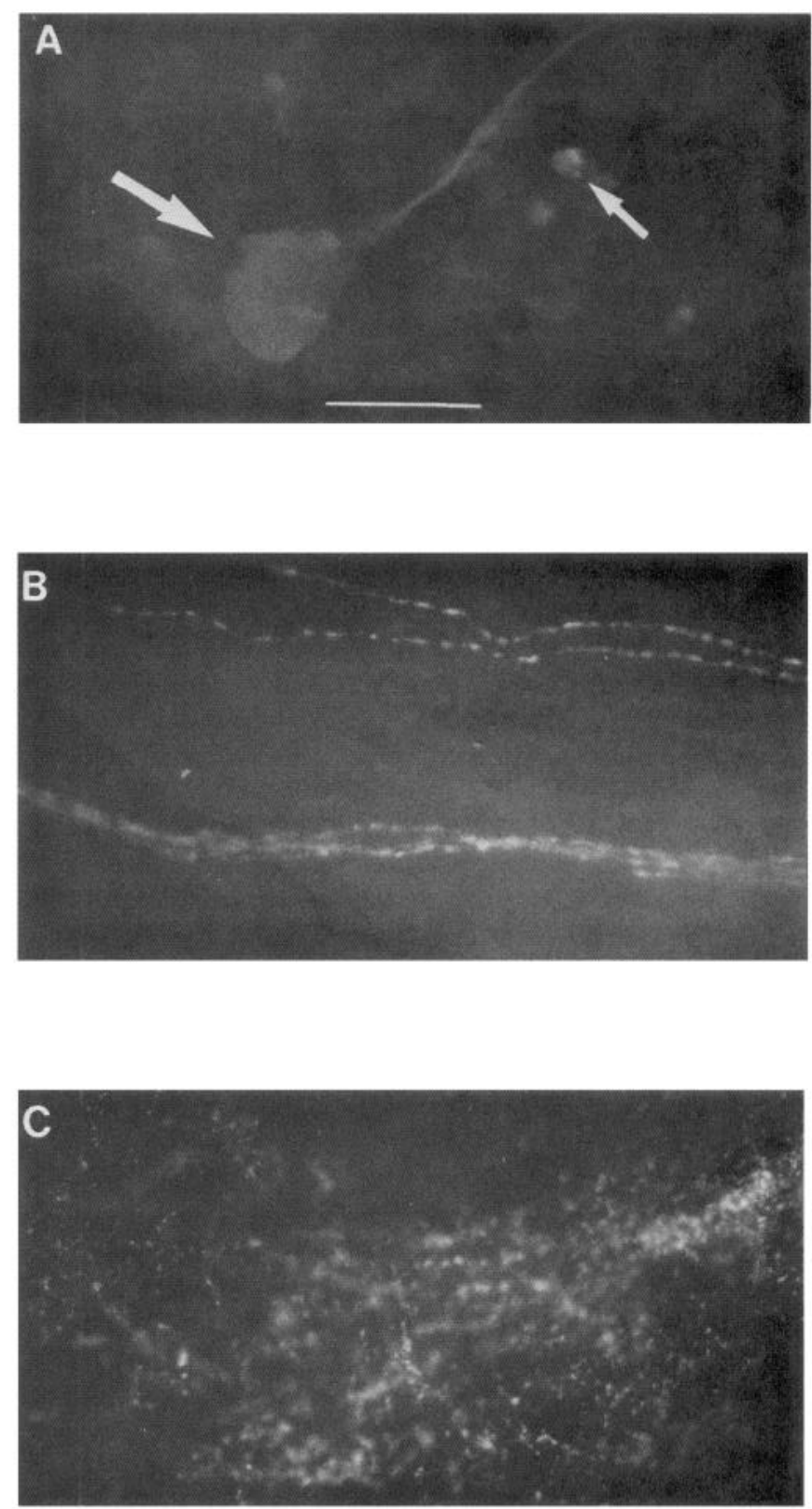

Figure 5. CCKE in the CGs and brain, using antiserum A. A, One large cell in the CG with a bifurcating process (large arrow) and one smaller cell (small arrow). B, Fibers in the optic nerve, close to where it enters the brain. $C$, Dense neuropilar staining in the brain. Scale bar, $50 \mu \mathrm{m}$.

nerve (mvn) trace has activity of the VD cell (large unit) and the IC cell (small unit), and the lateral ventricular nerve (lvn) trace has activity of the LP cell (large unit) and the PY and PD cells (small units). When the stn was sucrose-blocked to remove most of the descending modulatory inputs from the CGs, the rhythmic activity of the pyloric circuit slowed and became weaker (Fig. $7 B$ ). When CCK was bath-applied to such sucroseblocked preparations $(n=3)$, it was able to enhance bursting in IC, VD, LP, and PD (Fig. 7C). The spike frequencies and number of spikes/burst were increased over the sucrose-blocked condition for these 4 neurons, but not for PY (Table 1). There was no appreciable effect on cycle frequency. The latency for 
Figure 6. Schematic representation of the pattern of CCKLI in the stomatogastric nervous system of Panulirus interruptus. There are 1-2 fibers or fiber bundles in the stn, neuropil in the STG (stippling), neuropil at the stn/son junction, and somata, fibers, and neuropil in the CGs. Not drawn to scale.

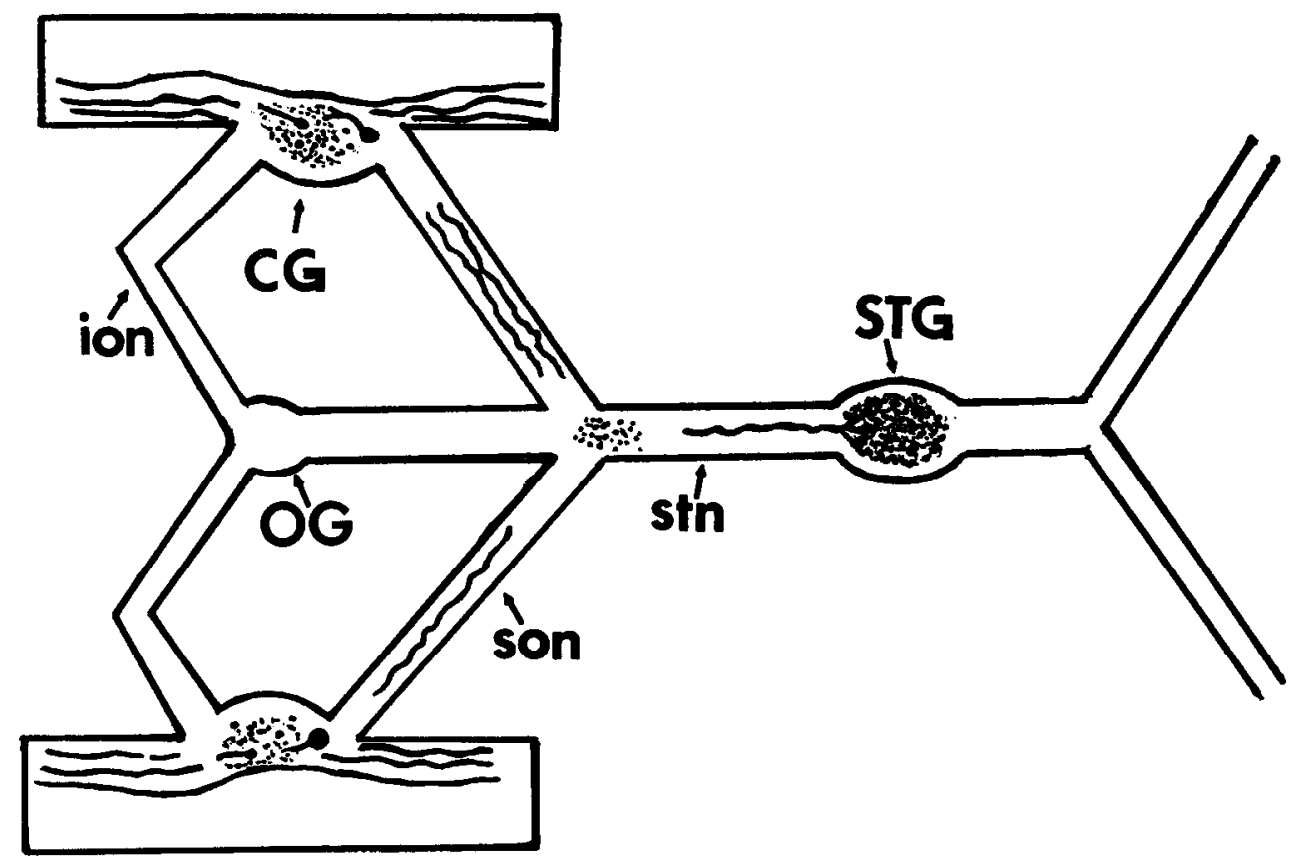

these effects was 2-10 min, and the effects were reversible (Fig. $7 D$ ) and could take 1-3 hr to wash out.

CCK can also modify the activity of pyloric neurons in an actively cycling preparation. One of the neurons strongly affected by CCK is the IC neuron; the effects of 2 different doses of CCK on the activity of the IC neuron is illustrated in Figure 8. CCK increased the size of the membranc potential oscillations and the spike frequency of IC in a dose-dependent manner (Fig. $8 \mathrm{~B}, \mathrm{C}$ ); after $1 \mathrm{hr}$ of wash, there was a partial reversal of these effects (Fig. 8D).

\section{Gastric CPG}

The gastric CPG is composed of 10 motoneurons and 1 interncuron which control the movements of 3 teeth in the lobster
A

\section{CONTROL}

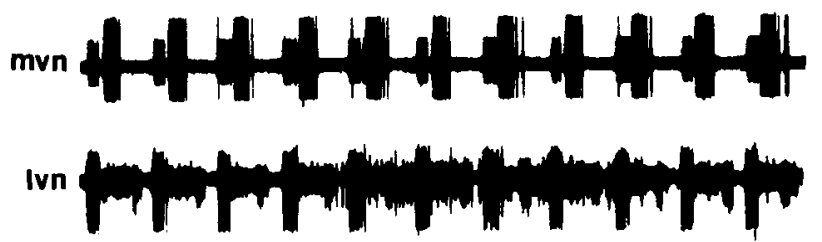

C

$$
\operatorname{ccK}\left(10^{-5}\right)
$$

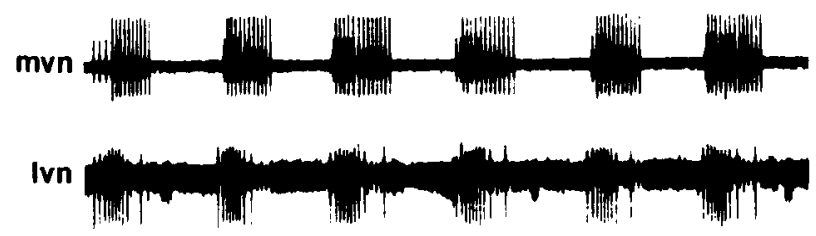

B

\section{SUCROSE BLOCK}

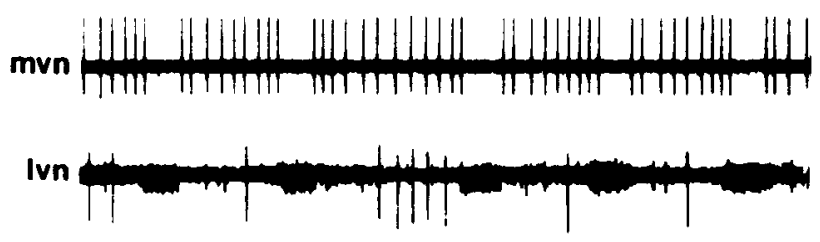

D

\section{WASH}

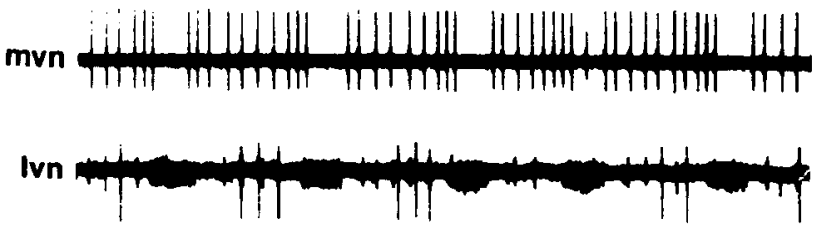

$1 s$

Figure 7. Effects of CCK on the pyloric motor pattern. $A$, Control activity of a vigorously cycling pyloric preparation. The mvn trace has activity of the IC neuron (small unit) and the VD neuron (large unit). The lvn trace has activity of the LP neuron (large unit) and the PY and PD neurons (small units). $B$, When inputs to the STG are blocked, the pyloric activity is greatly reduced. $C$, Bath application of $10^{-5} \mathrm{M} C \mathrm{CK}$ restores strong cycling that is qualitatively different from control activity. $D$, After several hours of superfusion with saline, the effects of CCK were reversed. 
Table 1. Effects of CCK on spike frequency and spikes/hurst of pyloric neurons

\begin{tabular}{lrrlll} 
& \multicolumn{2}{l}{$\begin{array}{l}\text { Average spike } \\
\text { frequency within burst }\end{array}$} & \multicolumn{2}{l}{ Spikes/burst } \\
\cline { 2 - 3 } \cline { 5 - 6 } Cell & Control & CCK & & Control & CCK \\
\hline PD & $18.9 \pm 2.4$ & $35.7 \pm 5.9$ & $6.0 \pm 0.8$ & $13.0 \pm 2.4^{a}$ \\
VD & $6.3 \pm 5.1$ & $15.7 \pm 9.1^{a}$ & & $5.5 \pm 3.6$ & $16.0 \pm 1.6^{a}$ \\
IC & $0.0 \pm 0.0$ & $14.1 \pm 4.7^{a}$ & & $0.0 \pm 0.0$ & $7.6 \pm 3.9$ \\
LP & $5.0 \pm 4.1$ & $18.8 \pm 6.6^{a}$ & & $1.0 \pm 1.0$ & $15.0 \pm 0.8^{a}$ \\
PY & $0.0 \pm 0.0$ & $0.0 \pm 0.0$ & & $0.0 \pm 0.0$ & $0.0 \pm 0.0$ \\
\hline
\end{tabular}

Data are expressed as mean \pm SEM for 3 preparations. Average spike frequency within a burst was calculated by dividing the number of spikes/burst by the burst duration. Values are for blocked control vs $5 \times 10^{-5} \mathrm{M} \mathrm{CCK}$.

${ }^{a} \mathrm{CCK}$ significantly different from control; $p<0.05$ (paired Student's $t$ distribution).

stomach. In the combined in vitro preparation, this CPG produces a stereotyped rhythm with characteristic phase relationships and a period of 5-10 sec. An example of this activity is given in Figure 1. The medial gastric neuron (MG) and lateral gastric neuron (LG) open the 2 lateral teeth; their activity is opposed by the 2 lateral posterior gastric neurons (LPG), which close the lateral teeth. The medial tooth is opened by the activity of the dorsal gastric neuron (DG) and is closed by the activity of the 4 gastric mill neurons (GM). An additional interneuron, interneuron 1 , acts to coordinate the activity of the lateral and medial tooth subsets. The gastric CPG is thus composed of the activity of 2 sets of antagonists; the number of phases has been considered to be anything from 2 to 5 (Selverston and Mulloney, 1974; Russell, 1985a,b).

When the STG is isolated from anterior ganglia by a sucrose block, all cyclical gastric mill activity stops within 2-3 min (Russell, 1976). Under these conditions, bath application of CCK was unable to restart gastric cycling, although occasionally DG and GM would alternate weakly at doses of $10^{-4} \mathrm{M}$. In some preparations, however, the gastric mill is spontaneously not cycling even though the inputs are intact (Fig. 9A), and under these conditions bath application of CCK to the STG was able to start up a vigorous gastric pattern (Fig. 9B). The latency for this effect was around $20 \mathrm{~min}$, and it took 1-4 hr to wash out (Fig. 9C). The threshold for this effect was $5 \times 10^{-6} \mathrm{M}(n=3)$.

As with the pyloric pattern, CCK can modify the ongoing gastric rhythm in a dose-dependent manner, as illustrated in Figure 10 . The frequency of the gastric rhythm increases under the influence of CCK, as do the spike frequencies of the DG and anterior medial neuron (AM) (Fig. 10, $B, C$ ). The dosedependent effects of CCK on the spike frequency of DG are presented in Figure 11: the spike frequency of DG almost doubles under the influence of CCK, from $22.7 \pm 1.5$ to $40.1 \pm$ 1.2 spikes/sec (mean $\pm \mathrm{SD}$ ), and returns to baseline after 1-3 hr of wash.

Quantitative data from 10 experiments are presented in Table 2. As well as increasing the spike frequency of most of the gastric units, CCK produces significant changes in the percentage of the period during which several gastric units fire, a measure known as the duty cycle. CCK increases the duty cycle of DG significantly, from $0.39 \pm 0.01$ to $0.52 \pm 0.02$, and that of LPG increases from $0.70 \pm 0.04$ to $0.84 \pm 0.02$ (mean \pm SEM). The duty cycle of GM shows a tendency to decrease which is not significant, and the duty cycles of AM and LG are unaffected by CCK. There is also a significant phase shift in LG and GM
A. CONTROL
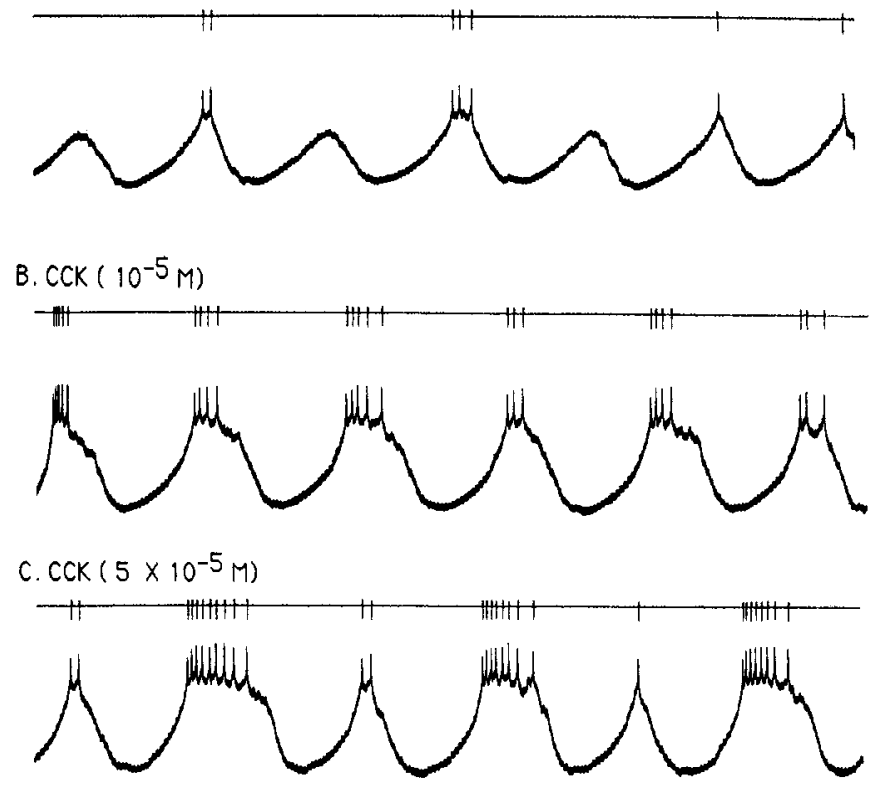

D. WASH
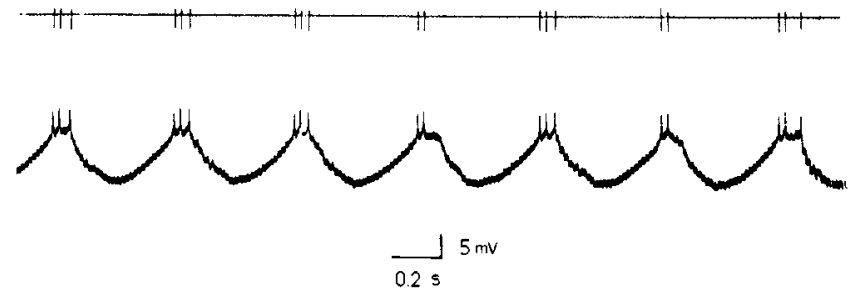

Figure 8. Dose-response of the IC neuron to bath application of CCK. $A$, Saline control. $B, \mathrm{CCK}$ at $10^{-5} \mathrm{M}$ increased the amplitude of membrane potential oscillations and the number of spikes/burst. $C$, The effect was greater at $5 \times 10^{-5} \mathrm{M}$. $D$, One-hour wash with saline; the size of the membrane potential oscillations returned to control values. No protease inhibitor was used in this experiment.

relative to the beginning of the DG burst (Table 2), so that LG and $G M$ fire later in the cycle. The phase of $L G$ increases from $0.34 \pm 0.04$ to $0.44 \pm 0.02$, and that of $\mathrm{GM}$ increases from $0.40 \pm 0.01$ to $0.47 \pm 0.01$ (mean $\pm \mathrm{SEM}$ ). The overall effect of thesc changes is to emphasize the phases of the gastric cycle responsible for opening the medial and lateral teeth (DG and LPG).

The effect of CCK on the period of the gastric pattern was dependent on the initial state of the preparation. In preparations where the control activity was weak or the cycle period was longer than $6 \mathrm{sec}$ CCK would decrease the period in a dosedependent manner (Fig. 10), from $7.5 \pm 1.2$ to $5.5 \pm 0.6 \mathrm{sec}$ $(n=10)$. However, in strongly cycling preparations where the bursts were vigorous and the period was under $6 \mathrm{sec}$, the period lengthened when CCK was applied, from $5.3 \pm 0.2$ to $8.6 \pm$ $0.3 \mathrm{sec}(n=4)$. This effect is illustrated in Figure 12 . At $10^{-5} \mathrm{M}$ CCK there is an initial decrease in period accompanied by an increase in spike frequencies of the gastric units and an augmentation of the membrane potential oscillations of AM (Fig. $12 B)$. At higher concentrations, however, the period begins to lengthen, due largely to an increase in the burst lengths of DG and LPG (Fig. 12, C, D). The duty cycles of DG and LPG 

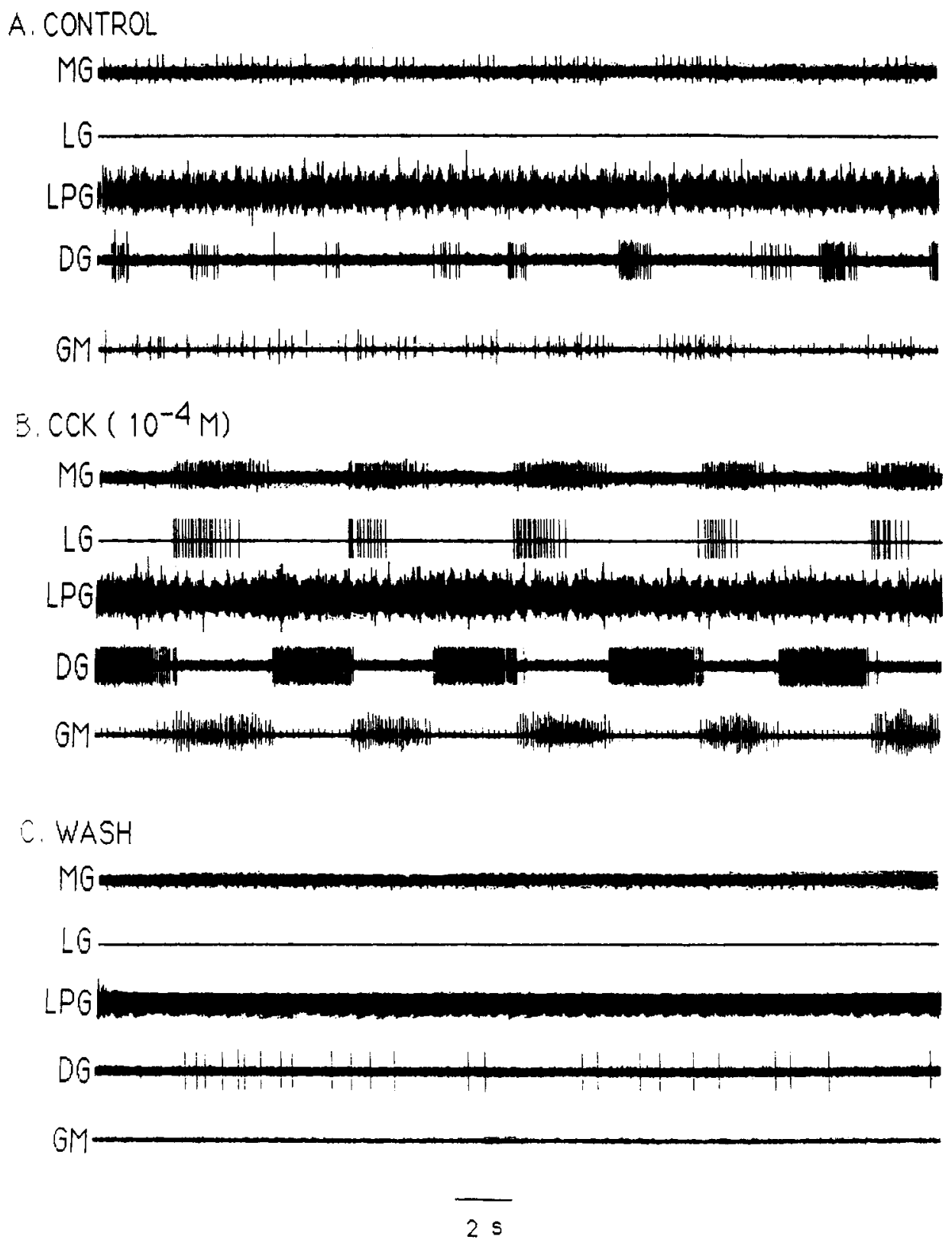

Figure 9. Effects of CCK on the gastric motor pattern. $A$, Spontaneously noncycling preparation. $B, \mathrm{CCK}$ at $10^{-4} \mathrm{M}$ started up strong cycling in all gastric units. $C$, After one hour of wash, the cycling stopped.

increase as they do when CCK produces a shortening of the period, but the duty cycles of GM, LG, and MG decrease, the spike frequencies of most units decrease, and AM becomes depolarized and oscillates only weakly under these conditions. Such state-dependent effects of a neuromodulator have also been reported for proctolin, on both the gastric and the pyloric systems (Marder et al., 1986; Heinzel and Selverston, 1988).

\section{Release Experiment}

The presence of CCKLI in the stomatogastric nervous system and the ability of CCK 8 to modulate the output of the STG suggest that a CCK-like peptide is an endogenous neuromodulator in lobster. We therefore wished to determine if this peptide could be released into the STG. Ideally, one would like to selectively stimulate an identified neuron which displays CCKLI and is known to project to the STG. As we have not yet identified such a neuron, we stimulated the entire stn, which we know contains fibers which display CCKLI.
The experimental protocol is illustrated in Figure 13. The desheathed STG was surrounded by a vaseline well of approximately $10 \mu \mathrm{l}$, the stn was stimulated for $1 \mathrm{hr}$ at $20 \mathrm{~Hz}$, and the superfusate was collected and assayed by RIA as described in Materials and Methods. Stimulation of the stn produced longlasting modulatory cffects on the output of the STG (Fig. 13B), suggesting that the stimulus was effective in releasing modulatory substances into the ganglion. As the stn contains many axons, such a stimulation paradigm would release many different substances into the STG, so the effects of stimulation cannot be attributed to the actions of any one substance.

The averaged results of 10 experiments are presented in Figure 14. For the unstimulated controls, $13.7 \pm 4.9$ fmol (mean \pm SEM) of CCKE were released, whereas stimulation of the stn produced a significant increase in the amount of CCKE released $(37.1 \pm 7.1 \mathrm{fmol})$. To determine if this release of CCKE was calcium dependent, we stimulated the stn after replacing calcium with magnesium in the superfusate; the levels of CCKE under 


\section{A.CONTROL}

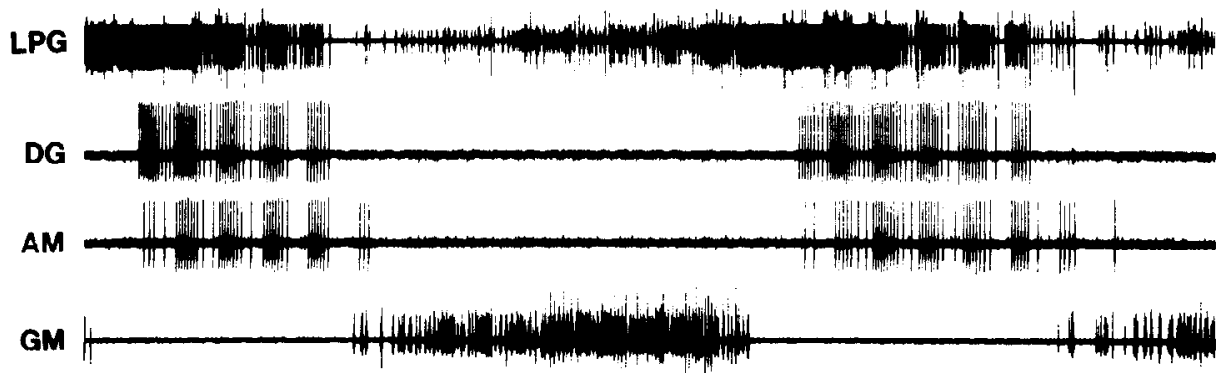

\section{B. CCK $\left(10^{-5} \mathrm{M}\right)$}

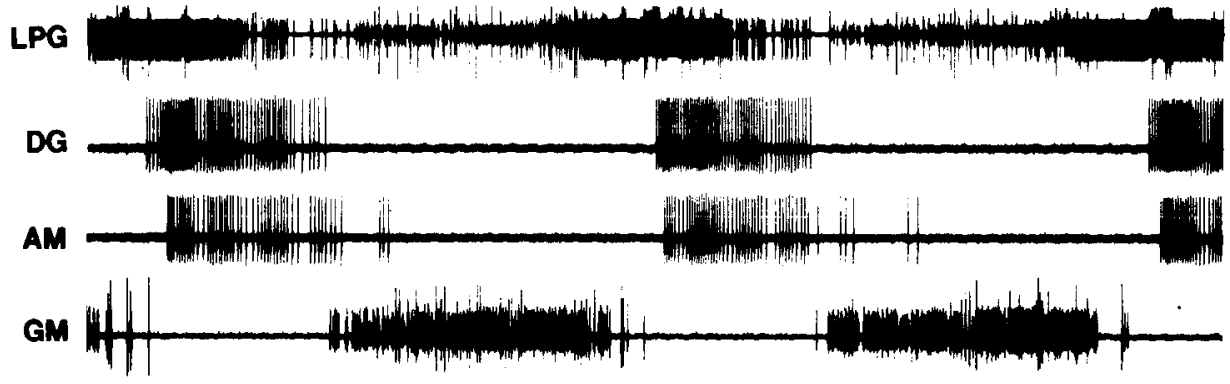

\section{CCK $\left(10^{-4} \mathrm{M}\right)$}

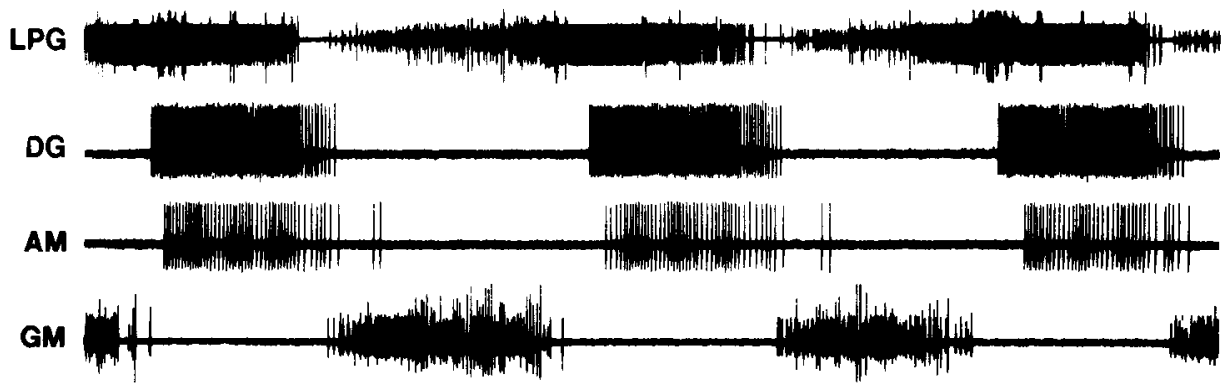

15
Figure 10. Dose-response of the ongoing gastric motor pattern to bath application of CCK. $A$, Control activity; note the periodic interruptions of the DG and AM bursts by pyloric input. $B$, CCK at $10^{-5} \mathrm{M}$ decreased the period of the gastric pattern and increased the spike frequency of DG and AM. $C, A t$ $10^{-4} \mathrm{M}$ these changes were more exaggerated, and the modulation of the DG and AM bursts by the pyloric system was almost gone. The GM burst length decreased greatly, whereas the DG and AM burst lengths remained about the same.

\section{Table 2. Effects of CCK on the spike frequency, duty cycle, and phase of gastric neurons}

\begin{tabular}{|c|c|c|c|c|c|c|c|}
\hline \multirow[b]{2}{*}{ Cell } & \multirow[b]{2}{*}{$\mathbf{N}$} & \multicolumn{2}{|c|}{$\begin{array}{l}\text { Spike frequency } \\
\text { within burst }\end{array}$} & \multicolumn{2}{|l|}{ Duty cycle } & \multicolumn{2}{|l|}{ Phase } \\
\hline & & Control & $\mathrm{CCK}$ & Control & $\mathrm{CCK}$ & Control & CCK \\
\hline LG & 5 & $10.9 \pm 2.4$ & $17.9 \pm 1.7^{a}$ & $0.37 \pm 0.06$ & $0.39 \pm 0.03$ & $0.34 \pm 0.04$ & $0.44 \pm 0.02^{a}$ \\
\hline LPG & 5 & $40.3 \pm 6.6$ & $41.4 \pm 6.5$ & $0.70 \pm 0.04$ & $0.84 \pm 0.02^{u}$ & $0.64 \pm 0.06$ & $0.64 \pm 0.06$ \\
\hline DG & 10 & $21.8 \pm 2.8$ & $32.5 \pm 2.8^{b}$ & $0.39 \pm 0.01$ & $0.52 \pm 0.02^{b}$ & $0.0 \pm 0.0$ & $0.0 \pm 0.0$ \\
\hline $\mathrm{AM}$ & 6 & $11.8 \pm 1.9$ & $21.5 \pm 1.2^{b}$ & $0.47 \pm 0.49$ & $0.49 \pm 0.04$ & $0.02 \pm 0.01$ & $0.02 \pm 0.01$ \\
\hline GM & 9 & $34.8 \pm 4.0$ & $38.1 \pm 4.7$ & $0.53 \pm 0.03$ & $0.47 \pm 0.02$ & $0.40 \pm 0.01$ & $0.47 \pm 0.01^{b}$ \\
\hline
\end{tabular}

Data arc exprcssed as the mcan + SEM. Valucs are for unblocked control vs $5 \times 10^{-5} \mathrm{M}$ CCK. Spike frequency within a burst was calculated by dividing the number of spikes/burst by the burst duration. Duty cycle was calculated by dividing the burst duration by the period. Phase was calculated as the beginning of the burst relative to the beginning of the DG burst.

${ }^{a}$ CCK significantly different from control; $p<0.05$.

${ }^{b} p<0.01$ (paired Student's $t$ distribution). 
Figure 11. Spike frequency of DG for 3 different doses of CCK. Bars indicate the mean spike frequency $\pm S D$ of $D G$ for the 5 conditions. Thirty-minute washes were interspersed between the different doses of CCK. Wash is the final wash. *, Different from control; $p$ $<0.01$ (Student's $t$ test).

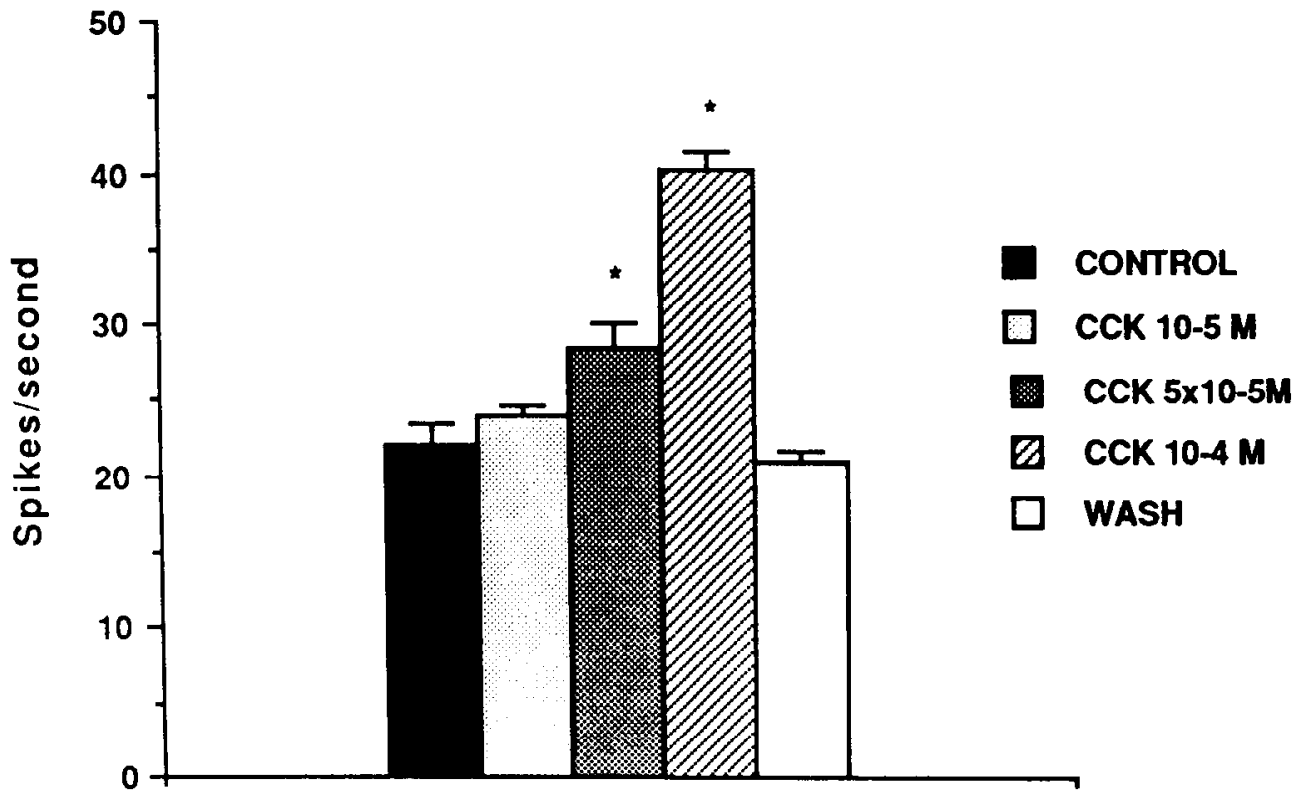

these conditions were not distinguishable from zero $(4.9 \pm 2.9)$. These results were consistent regardless of the order in which the manipulations were performed; however, the effects of zero calcium were only partially reversible. After replacement of calcium, no CCKE were detectable in control conditions. In the 4 experiments in which stimulation with calcium followed stimulation in zero calcium, the amount of CCKE released was 18.3 $+5.5 \mathrm{fmol}$. This is still within the levels of detection of this assay and is significantly more than the zero calcium condition. This decrease in the amount of releasable CCKE may reflect damage done to the nerve terminals by the absence of calcium or an incomplete replacement of calcium when the ganglion is returned to normal saline. Without a protease inhibitor present in the superfusate, there was no detectable release under any condition.

Cumulative release of CCKE over time is plotted in Figure 15 , which represents data averaged from 4 experiments. In this experiment, 30 -min bouts of stimulation were interspersed with 30 -min controls. After $2.5 \mathrm{hr}$ of cumulative stimulation, the rcleasc of CCKE had begun to level off; in 3 of the 4 cxperiments performed, the release had leveled off completely by $2 \mathrm{hr}$. The amount of CCKE releasable from one ganglion after $2.5 \mathrm{hr}$ of cumulative stimulation was $70 \pm 11.7 \mathrm{fmol}$ (mean \pm SEM). This number is probably an underestimate, for several reasons. (1) Recovery was estimated by adding $50 \mathrm{fmol}$ of CCK to the vaseline well at the end of the experiment (after removing the STG), allowing it to sit for $30 \mathrm{~min}$, and removing it and assaying it in the RIA. Recovery was $60-70 \%$ for this procedure but is probably less for the endogenous peptide, which must diffuse out of the ganglion and into the bath. (2) The RIA may underestimate the amount of peptide present, owing to poor crossreactivity of the endogenous peptide with the antiserum. (3) We may not have completely abolished protease activity.

Seventy femtomol represent about one-third of the total amount of FMRFamide or proctolin estimated by RIA to be in one Panulirus STG (Marder et al., 1986, 1987). Preliminary attempts to measure the total amount of CCKE in one STG suggest there is on the order of 100-200 fmol of CCKE/STG, but due to negative interference of whole Panulirus tissue ex- tracts in the RIA, this number is an underestimate, and no accurate measure has yet been made. Other workers have encountered similar problems with measuring whole extracts in RIA (Dockray ct al., 1981; Marder ct al., 1987).

\section{Discussion}

CCK-like peptides have now been identified in the nervous systems of a number of vertebrates and invertebrates (Vigna, 1985 ) and have been shown to affect invertebrate gut motility (Nachman et al., 1986), but in only one invertebrate to date has a direct neurophysiological effect of CCK 8 been demonstrated; CCK has been shown to modify calcium currents in identified neurons in snail (Hammond et al., 1987). In this paper we have shown that a CCK-like peptide is present in the stomatogastric nervous system of the lobster, Panulirus interruptus, and can be released into the STG upon stimulation of the input nerve. In addition, bath application of CCK to the STG can modulate the output of the pyloric and gastric mill CPGs and therefore the rhythmic activity of the digestive tract. These data support the hypothesis that an endogenous CCK-like pcptide acts as a neuromodulator of this system, thus establishing a neuronal role for a CCK-like peptide in the control of gut function in an invertebrate. We discuss these data, and the possible limitations of our findings, below.

\section{Immunocytochemistry}

We have used 2 antisera against CCK, one obtained commercially and the other raised in our laboratory, to map out the pattern of CCKLI in the stomatogastric nervous system of Panulirus interruptus. Both antisera produced a similar pattern of staining; there is dense neuropilar staining within the STG, but none of the somata of the STG stain. In this regard the staining pattern resembles that observed in Panulirus interruptus for several other substances, including FMRFamide (Marder et al., 1987), proctolin (Marder et al., 1986), and dopamine (Kushner and Barker, 1983).

The source of the CCKLI in fibers and neuropil of the stn and STG is not clear. Candidate structures, where somata containing CCKLI were observed, are the CGs and the brain. The 


\section{A. CONTROL}

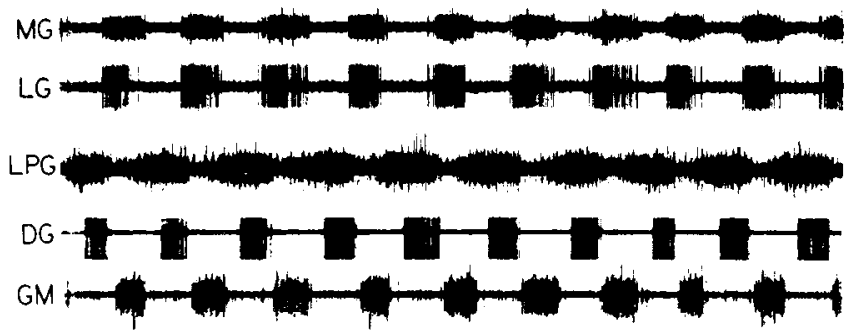

$\mathrm{AM}$

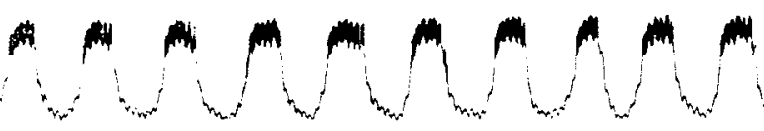

C. $\operatorname{CCK}\left[5 \times 10^{-5} \mathrm{M}\right]$

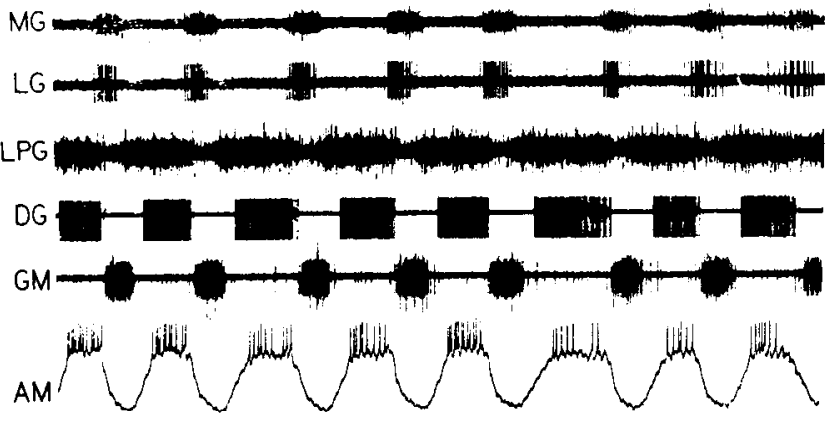

B. $\operatorname{CCK}\left(10^{-5} \mathrm{M}\right)$

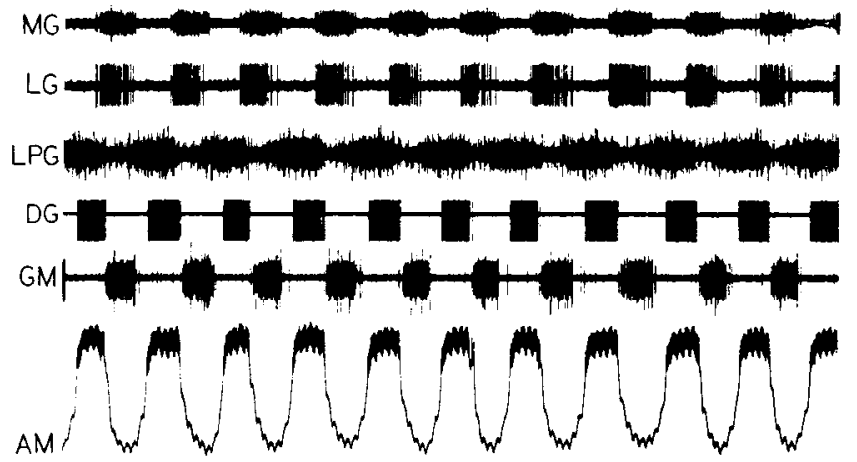

D. CCK $\left\{10^{-4} \mathrm{M}\right]$

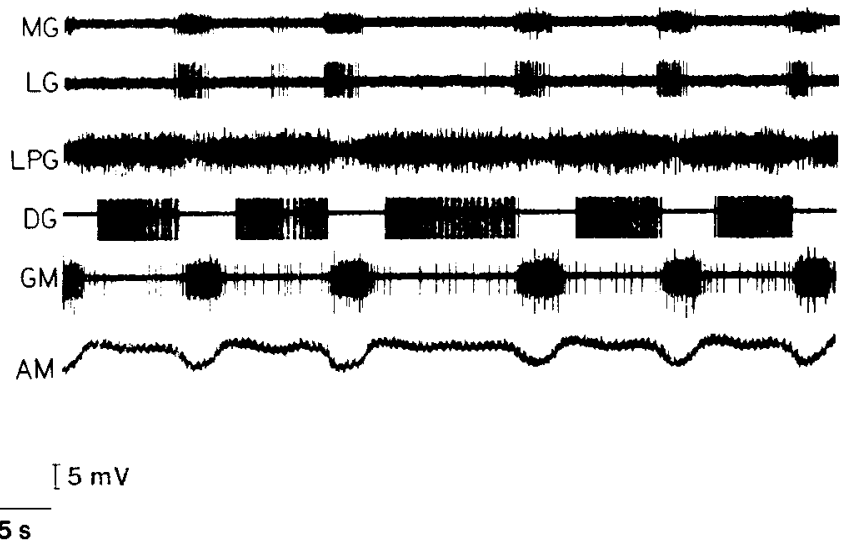

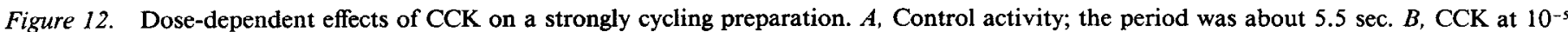

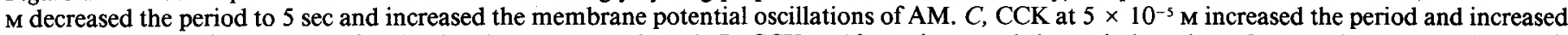

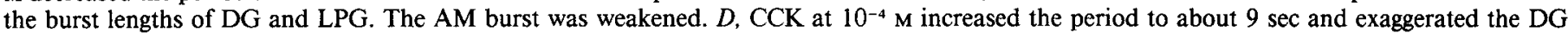
and LPG burst lengths still further.

CGs contain a number of neurons that are known to synapse onto elements in the STG (Robertson and Moulins, 1981a, b; Nagy and Moulins, 1987) as well as somata which are immunoreactive for a number of putative modulators (Beltz et al. 1984; Marder et al., 1986, 1987). Wherever the somata are located, their projection to the STG may be by way of the sons, which in some preparations were seen to contain one or more immunoreactive fibers. It was not possible to combine Lucifer yellow backfills of the sons with staining in order to doublelabel CG somata, because in order to stain somata it was necessary to pretreat the lobsters with colchicine.

There have been several previous immunocytochemical studies of CCK-like peptides in crustacea. Scalise et al. (1984) reported the presence of immunoreactive epithelial cells in crab stomach. Larson and Vigna (1983a) used RIA to detect CCKLI in crab stomach extracts and in hemolymph, but did not detect significant levels of immunoreactivity in the crab nervous system. This may reflect the level of detection of their assay, which varied from tissue to tissue. Favrel et al. (1987) detected CCKLI in stomach epithelial cells and in neurosecretory cells and axons in the eyestalks of prawn. It is possible that this staining corresponds to the staining we observed in axons in the optic nerve. In addition, Favrel (1988) demonstrated that levels of CCKLI in hemolymph increase immediately after feeding in prawn.
These data suggest that circulating levels of a CCK-like peptide may play a role in the regulation of feeding behavior or metabolism. The STG is situated in the ophthalmic artery close to the heart, where it is in a good position to respond to hormones borne in the hemolymph. Another route by which CCK-like peptides could modulate the output of the STG is thus through the hemolymph.

\section{Physiology}

Both the pyloric and the gastric mill CPGs within the STG of Panulirus interruptus respond to the bath application of CCK to the STG in a consistent, dose-dependent, and reversible manner. In a sucrose-blocked preparation, CCK can increase the spike frequencies and number of spikes/burst of most pyloric neurons, but it has only a minor effect on the overall frequency of the rhythm. This is in contrast to most other modulators of the pyloric rhythm, which increase the pyloric frequency (Marder, 1987).

Many substances have been described that can modulate the output of the pyloric circuit (Marder, 1987; Harris-Warrick, 1988), but comparatively little is known about the capacity for flexibility of the gastric circuit. CCK can induce cycling in a quiescent gastric system if the inputs from the stomatogastric nerve are left intact. It is possible that a certain level of tonic 
A

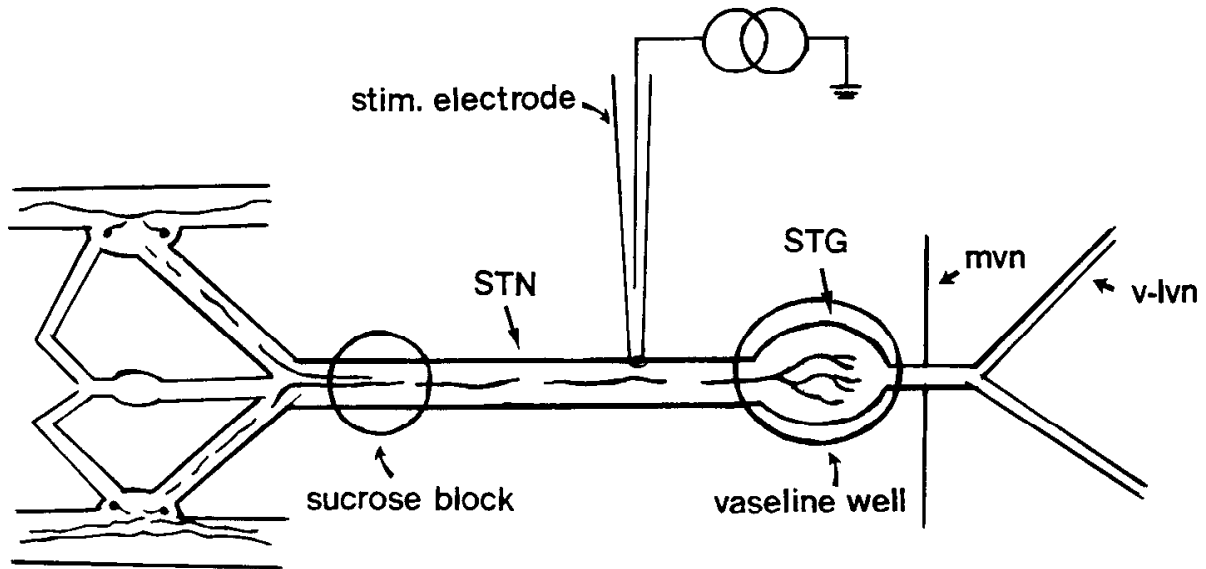

B

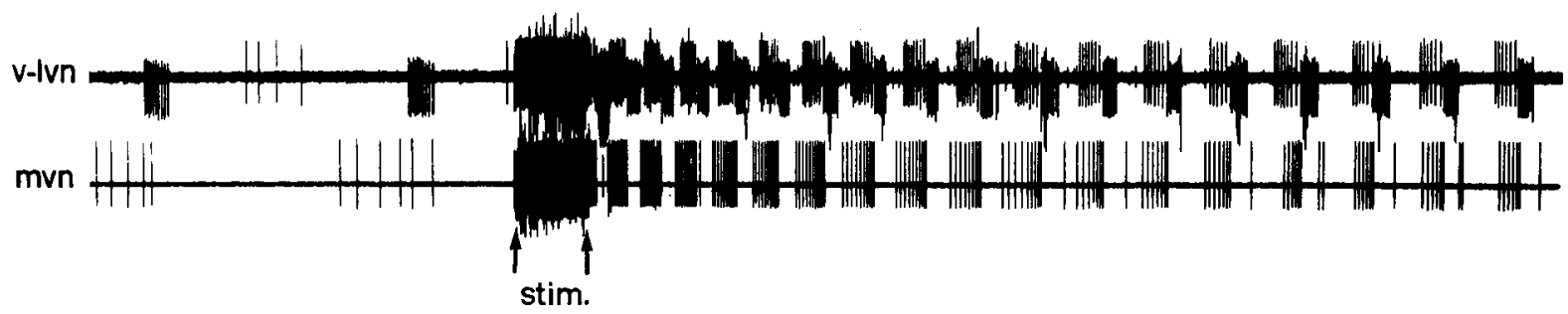

Figure 13. Release experiment. A, Schematic representation of the release experiment showing the configuration of the stimulating electrode and the recording electrodes. The STG was desheathed and surrounded by a $10 \mu \mathrm{l}$ vaseline well, and the stn was sucrose blocked. The stn, which contains many axons, including fibers that are immunoreactive to $\mathrm{CCK}$, was stimulated on the ganglion side of the sucrose block. The superfusate around the ganglion was then collected and assayed for CCKE as described in the text. $B$. The effects of stimulation of the stn on the output of the STG. Prior to stimulation, the sucrose-blocked preparation cycles only weakly. Stimulation of the stn at $20 \mathrm{~Hz}$ for 2 sec (between arrows) has profound modulatory effects on the output of the STG, which outlasts the stimulation by many minutes. Prior to each experiment, the current was adjusted until this effect was obtained; the effect was stable throughout the experiment.

Figure 14. Calcium-dependent release of CCKE. Each bar represents the mean amount of CCKE released into the STG in $1 \mathrm{hr} \pm \mathrm{SD}$. For the zero calcium condition, calcium was replaced with magnesium. The 3 conditions are statistically different from one another at the $p<0.002$ level (one-way ANOVA). ${ }^{* *}$, Stimulation with calcium is significantly different from control ( $p$ $<0.003$, paired Bonferroni $t$ test). ${ }^{*}$ Stimulation with calcium is significantly different from stimulation in zero calcium $(p<0.01$, unpaired Bonferroni $t$ test). Control and stimulation with calcium, $n=10$. Stimulation in zero calcium, $n=6$.

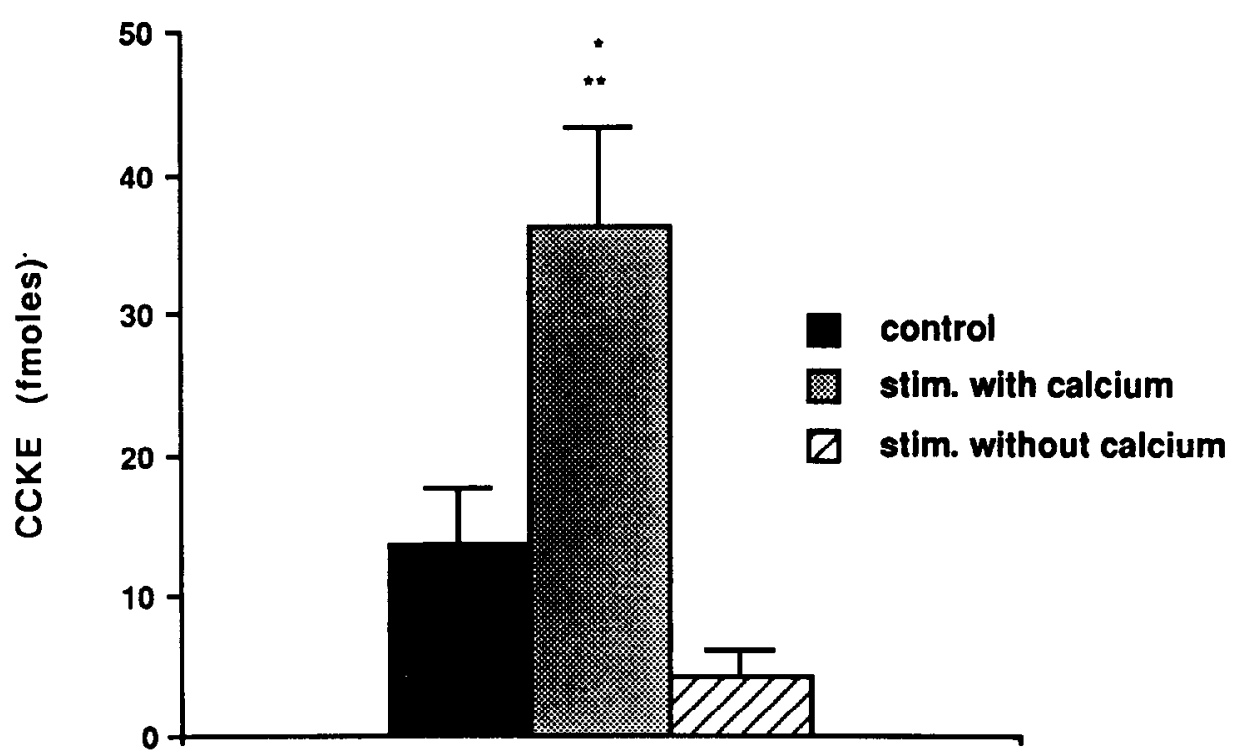


excitatory input is necessary for the effects of CCK on the gastric system to be expressed; alternatively, CCK may enable the expression of some other modulatory input. The most consistent and dramatic effects of CCK on an ongoing gastric rhythm are to increase the duty cycles of DG and LPG, which open the medial and lateral teeth, and to increase the spike frequencies of DG, AM, and LG. The best-described modulator of the gastric rhythm is proctolin (Heinzel, 1988b; Heinzel and Selverston, 1988), which produces effects that are quite different from CCK. Although proctolin increases the duty cycle and the spike frequency of DG, as does CCK, proctolin also acts to greatly increase the duty cycles of LG/MG and GM, which close the tccth, and to decrease the duty cycle of LPG. It therefore appears that the gastric CPG, like the pyloric CPG, can produce several different stable patterns depending on the nature of the modulatory influence.

Unlike most modulatory peptides, the threshold for the effects of CCK on the STG is very high; significant changes in the output of the gastric and pyloric CPGs are not produced until $10^{5} \mathrm{M}$. This is several orders of magnitude higher than the threshold for proctolin effects (Hooper and Marder, 1987; Heinzel and Selverston, 1988). There are several possible explanations for this phenomenon. First, the CCK-like peptide may act more like a conventional neurotransmitter than a hormone in the STG. The CCK-like projection may form specific synapses with select neurons in the circuit, and the local concentration of peptide at a specific synapse may build up quite high. In this case, bath application of CCK might fail to mimic the effects of the endogenous peptide. The diffuse nature of the staining pattern observed in the STG, with seemingly the entire neuropil containing CCKLI, suggests that this is not the case, but rather that the peptide is released globally into the entire ganglion, as has been proposed for other peptides in this system (Marder et al., 1986, 1987) and other systems (Jan and Jan, 1982). Furthermore, the time course of action of $\mathrm{CCK}$, with latencies of 5-20 min, along with the long wash time, suggests a modulatory rather than a transmitter function (Kupfermann, 1979).

A second and more likely possibility is that the endogenous peptide is similar but not identical to $\mathrm{CCK}$, and that $\mathrm{CCK}$ therefore has a low affinity for the receptors in the ganglion. This appears to be the case for another peptide modulator of the STG, FMRFamide: the neuropil of the STG shows FMRFlike immunoreactivity, but it takes on the order of $10^{5} \mathrm{M}$ FMRFamide to produce a modulatory effect on the output of the STG (Hooper and Marder, 1984). Subsequent biochemical characterization of FMRFamide-like peptides in crustacea has demonstrated that there are several such peptides, none of which are authentic FMRFamide (Marder et al., 1987; Trimmer et al., 1987; Kobierski et al., 1987). Although immunocytochemistry has demonstrated the presence of CCK-like peptides in a number of invertebrates (Vigna, 1985), only 2 such peptides have been sequenced, leukosulfakinin and drosulfakinin (Nachman et al., 1986; Nichols et al., 1988). Both of these peptides share only 5 of the 8 amino acids present in CCK8. Favrel and colleagues have isolated and purified $3 \mathrm{CCK}$-like peptides from the stomach of the crustacean Palaemon serratus (prawn) (Favrel et al. 1987; Favrel, 1988); although they have not yet sequenced these peptides, the amino acid compositions are distinct from that of CCK8 (Favrel, 1988). It therefore appears likely that the CCK-like peptide endogenous to lobster has a distinct sequence from that of mammalian CC.K. We are currently involved in a collaboration with P. Favrel and A. Van Wormhoudt to test the

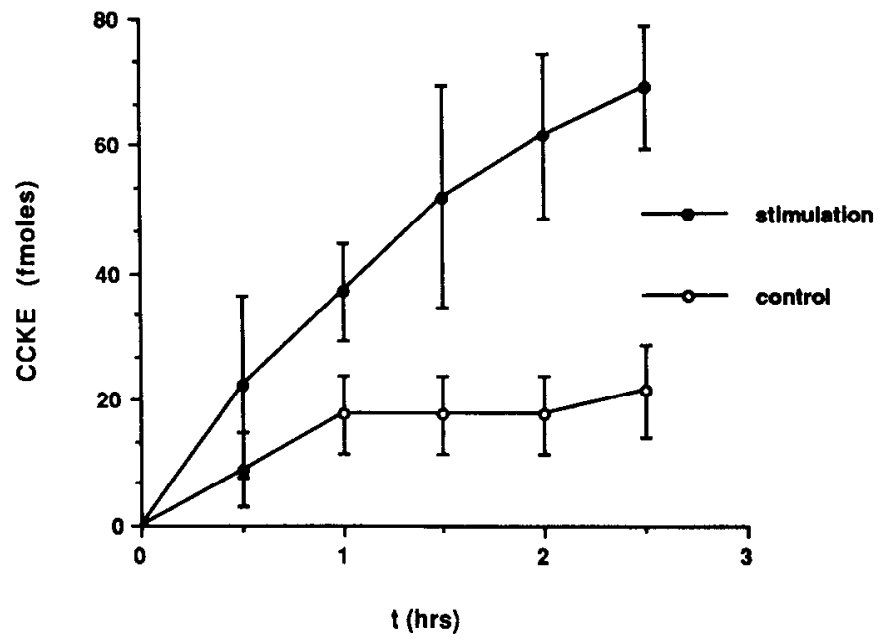

Figure 15. Cumulative release of CCKE. The stn was stimulated in 30-min bouts, and the cumulative amount of CCKE plotted over time. Thirty-minute controls were interspersed between stimulation bouts. $n$ $=4$.

physiological effects of their purified CCK-like peptides; preliminary results indicate that concentrations as low as $10^{-8} \mathrm{M}$ have dramatic effects on the output of the STG (unpublished observations) which are in many respects similar to the effects of CCK.

\section{Release of CCKLI into the STG}

Stimulation of the stn at an intensity that produces modulatory effects on the pyloric CPG can increase the levels of CCKE detectable in the superfusate of the STG in a calcium-dependent manner. This experiment demonstrates that the CCKLI in fibers in the stn and STG represents a pool of releasable material, and it strengthens the argument that a CCK-like peptide acts as an endogenous modulator of the circuits in the STG. This is the first demonstration that a putative modulator of the STG can be released directly into the ganglion.

Measurable amounts of CCKE are also released under control conditions, when traffic in the stn is blocked and there is no stimulation. This probably does not reflect leakage due to damage of terminals during desheathing, since in zero calcium saline (with or without stimulation) there are no detectable CCKE released. Instead, it suggests that neuromodulators may be released into the STG in small amounts in a tonic fashion, such that the ganglion is always operating under the influence of low levels of modulators. This conclusion must be reached with caution as the levels of CCKE measured under control conditions are close to the limits of detection of our RIA. It is also possible that there is some calcium-independent release that we were unable to detect.

In summary, we have presented 3 lines of evidence that a CCK-like peptide acts as a modulator of the STG in the lobster Panulirus interruptus: (1) There is CCKLI in the stomatogastric nervous system; (2) bath application of $\mathrm{CCK} 8 \mathrm{SO}_{4}$ to the STG modulates the output of both the pyloric and the gastric mill CPGs; and (3) stimulation of the stn produces release of CCKE into the STG. A CCK-like peptide thus joins a growing list of endogenous substances that are thought to modulate the output of the STG. 


\section{Appendix}

List of abbreviations

$\begin{array}{ll}\text { AB, } & \text { anterior burster neuron } \\ \text { aln, } & \text { anterior lateral nerve } \\ \text { AM, } & \text { anterior medial neuron } \\ \text { amn, } & \text { anterior medial nerve } \\ \text { CCK, } & \text { cholecystokinin } \\ \text { CCK8SO }, & \text { cholecystokinin } 8 \text { sulfate } \\ \text { CCKE, } & \text { cholecystokinin molar equivalents } \\ \text { CCKLI, } & \text { cholecystokinin-like immunoreactivity } \\ \text { CG, } & \text { commissural ganglion } \\ \text { CPG, } & \text { central pattern generator } \\ \text { DG, } & \text { dorsal gastric neuron } \\ \text { dgn, } & \text { dorsal gastric nerve } \\ \text { d-lvn, } & \text { dorsal lateral ventricular nerve } \\ \text { FMRFamide, } & \text { phe-met-arg-phe-amide } \\ \text { GM, } & \text { gastric mill neuron } \\ \text { IC, } & \text { inferior cardiac neuron } \\ \text { ion, } & \text { inferior eosophageal nerve } \\ \text { LG, } & \text { lateral gastric neuron } \\ \text { LP, } & \text { lateral pyloric neuron } \\ \text { LPG, } & \text { lateral posterior gastric neuron } \\ \text { lvn } & \text { lateral ventricular nerve } \\ \text { MG, } & \text { medial gastric neuron } \\ \text { mvn, } & \text { medial ventricular nerve } \\ \text { OG, } & \text { eosophageal ganglion } \\ \text { ON, } & \text { eosophageal nerve } \\ \text { PD, } & \text { pyloric dilator } \\ \text { PY, } & \text { pyloric neuron } \\ \text { RIA, } & \text { radioimmunoassay } \\ \text { RPCH, } & \text { red pigment concentrating hormone } \\ \text { son, } & \text { superior eosophageal nerve } \\ \text { STG, } & \text { stomatogastric ganglion } \\ \text { stn, } & \text { ventral dilator } \\ \text { VD, } & \\ \text { v-lvn, } & \end{array}$

\section{References}

Baile, C. A., and M. A. Della-Fera (1985) Central nervous system cholecystokinin and the control of feeding. Ann. NY Acad. Sci. 448: 424-430.

Beltz, B. S., and E. A. Kravitz (1983) Mapping of serotonin-like immunoreactivity in the lobster nervous system. J. Neurosci. 3: 585602.

Beltz, B. S., J. S. Eisen, R. Flamm, R. M. Harris-Warrick, S. L. Hooper, and E. Marder (1984) Serotonergic innervation and modulation of the stomatogastric ganglion of three decapod crustaceans (Panulirus interruptus, Homarus americanus, and Cancer irroratus) J. Exp. Biol. 109: 35-54.

Brooks, P. A., and J. S. Kelly (1985) Cholecystokinin as a potent excitant of neurons of the dentate gyrus of rats. Ann. NY Acad. Sci. 448: 361-374.

Dockray, G. J. (1976) Immunochemical evidence of cholecystokininlike peptides in brain. Nature 264: 568-570.

Dockray, G. J. (1978) Comparative biochemistry and physiology of gut hormones. Annu. Rev. Physiol. 41: 83-95.

Dockray, G. J., H. Duve, and A. Thorpe (1981) Immunochemical characterization of gastrin/cholecystokinin-like peptides in the brain of the blowfly, Calliphora vomitoria. Gen. Comp. Endocrinol. 45. $491-496$.

Duve, H., and A. Thorpe (1981) Gastrin/cholecystokinin-like immunoreactive neurons in the brain of the blowfly, Calliphora ery. throcepha (Diptera). Gen. Comp. Endocrinol. 43: 381-391.

Eisen, J. S., and E. Marder (1982) Mechanisms underlying pattern generation in lobster stomatogastric ganglion as determined by selec- tive inactivation of identified neurons. III. Synaptic connections of electrically coupled pyloric neurons. J. Neurophysiol. 48: 1392-1415.

Favrel, P. (1988) Purification et caractérisation biochimique de peptides immunologiquement apparentes aux gastrines/cholécystokinines chez quelques crustaces décapodes: Recherche d'un role biologique. Ph.D. dissertation, University of Rennes, Concarneau, France.

Favrel, P., A. Van Wormhoudt, J. M. Studler, and C. Bellows (1987) Immunochemical and biochemical characterization of gastrin/CCKlike peptides in Palaemon serratus (crustacea decapoda): Intermolt variations. Gen. Comp. Endocrin. 65: 363-372.

Flamm, R. E., and R. M. Harris-Warrick (1986a) Aminergic modulation in lobster stomatogastric ganglion. I. Effects on motor pattern and activity of neurons within the pyloric circuit. J. Neurophysiol. 55: $847-865$.

Flamm, E. R., and R. M. Harris-Warrick (1986b) Aminergic modulation in lobster stomatogastric ganglion. II. Target neurons of dopamine, octopamine, and serotonin within the pyloric circuit. J. Neurophysiol. 55: 866-881.

Goldberg, D., M. P. Nusbaum, and E. Marder (1988) Substance P-like immunoreactivity in the stomatogastric nervous systems of the crab Cancer borealis and the lobsters Panulirus interruptus and Homarus americanus. Cell Tissue Res. 252: 515-522.

Hammond, C., D. Paupardin-Tritsch, A. C. Nairn, P. Greengard, and H. M. Gerschenfeld (1987) Cholecystokinin induces a decrease in calcium current in snail neurons that appears to be mediated by protein kinase C. Nature 325: 809-811.

Harris-Warrick, R. M. (1988) Chemical modulation of central pattern generators. In Neural Control of Rhythmic Movements in Vertebrates, A. H. Cohen, S. Rossignol, and S. Grillner, eds., pp. 285-232, Wiley.

Heinzel, H. (1988a) Gastric mill activity in the lobster I. Spontancous modes of chewing. J. Neurophysiol. 59: 528-549.

Heinzel, H. (1988b) Gastric mill activity in the lobster. II. Proctolin and octopamine initiate and modulate chewing. J. Neurophysiol. 59: 566-585.

Heinzel, H., and A. I. Selverston (1988) Gastric mill activity in the lobster. III. Effects of proctolin on the isolated central pattern generator. J. Neurophysiol. 59: 566-585.

Hooper, S. L., and E. Marder (1984) Modulation of a central pattern generator by two neuropeptides, proctolin and FMRFamide. Brain Res. 305: 186-191.

Hooper, S. L., and E. Marder (1987) Modulation of the lobster pyloric rhythm by the peptide proctolin. J. Neurosci. 7: 2097-2112

Jan, J. Y., and Y. N. Jan (1982) Peptidergic transmission in sympathetic ganglia of the frog. J. Physiol. (Lond.) 327: 219-246.

Kobierski, L. A., B. A. Beltz, B. A. Trimmer, and E. A. Kravitz (1987) FMRFamidelike peptides of Homarus americanus: Distribution, immunocytochemical mapping, and ultrastructural localization in terminal varicosities. J. Comp. Neurol. 266: 1-15.

Kritzer, M. F., R. B. Innis, and P. S. Goldman-Rakic (1987) Regional distribution of cholecystokinin receptors in primate cerebral cortex as determined by in vitro receptor autoradiography. J. Comp. Neurol. 263: 418-435.

Kupfermann, I. (1979) Modulatory actions of neurotransmitters. Annu. Rev. Neurosci. 2: 447-465.

Kushner, P. D., and D. L. Barker (1983) A neurochemical description of the dopaminergic innervation of the stomatogastric ganglion of the spiny lobster. J. Neurobiol. 4: 17-28.

Larson, B. A., and S. R. Vigna (1983a) Gastrin/cholccystokinin-like immunoreactive peptides in the Dungeness crab, Cancer magister (Dana): Immunochemical and biological characterization. Reg. Peptides $7:$ 155-170.

Larson, B. A., and S. R. Vigna (1983b) Species and tissue distribution of cholecystokinin/gastrin-like substances in some invertebrates. Gen. Comp. Endocrinol. 50: 469-475.

Marder, E. (1987) Neurotransmitters and modulators. In The Crustacean Stomatogastric System, A. I. Selverston and M. Moulins, eds., pp. 263-306, Springer-Verlag, Berlin.

Marder, E., and J. Eisen (1984) Electrically coupled pacemaker neurons respond differently to the same physiological inputs and neurotransmitters. J. Neurophysiol. 51: 1362-1374.

Marder, E., S. L. Hooper, and K. Siwicki (1986) Modulatory action and distribution of the neuropeptide proctolin in the crustacean stomatogastric nervous system. J. Comp. Neurol. 243: 454-467.

Marder, E., R. L. Calabrese, M. P. Nusbaum, and B. Trimmer (1987) Distribution and partial characterization of FMRFamide-like pep- 
tides in the stomatogastric nervous systems of the rock crab, Cancer borealis, and the spiny lobster, Panulirus interruptus. J. Comp. Neurol. 259: 150-163.

Marley, P. D., J. F. Rehfeld, and P. C. Emson (1984) Distribution and chromatographic characterization of gastrin and cholecystokinin in the rat central nervous system. J. Neurochem. 42: 1523-1535.

Miller, J. P., and A. I. Selverston (1982a) Mechanisms underlying pattern generation in lobster stomatogastric ganglion as determined by selective inactivation of identified neurons. II. Oscillatory properties of pyloric neurons. J. Neurophysiol. 48: 1378-1391.

Miller, J. P., and A. I. Selverston (1982b) Mechanisms underlying pattern generation in lobster stomatogastric ganglion as determined by selective inactivation of identified neurons. IV. Network properties of pyloric system. J. Neurophysiol. 48: 1416-1432.

Mulloney, B., and A. I. Selverston (1974a) Organization of the stomatogastric ganglion in the spiny lobster. I. Neurons driving the lateral teeth. J. Comp. Physiol. 91: 1-32.

Mulloney, B., and A. I. Selverston (1974b) Organization of the stomatogastric ganglion in the spiny lobster. III. Coordination of the two subsets of the gastric system. J. Comp. Physiol. 91: 53-78.

Nachman, R. J., G. M. Holman, W. R. Haddon, and N. Ling (1986) Leucosulfakinin, a sulfated insect neuropeptide with homology to gastrin and cholecystokinin. Science 234: 71-73.

Nagy, F., and M. Moulins (1987) Extrinsic inputs. In The Crustacean Stomatogastric System, A. I. Selverston and M. Moulins, eds., pp. 205-262, Springer-Verlag, Berlin.

Nichols, R., S. A. Schneuwly, and J. E. Dixon (1988) Identification and characterization of a Drosophila homologue to the vertebrate neuropeptide cholecystokinin. J. Biol. Chem. 263: 12167-12170.

Nusbaum, M., and E. Marder (1988) A neuronal role for a crustacean red pigment concentrating hormone-like peptide: Neuromodulation of the pyloric rhythm in the crab, Cancer horealis. J. Exp. Biol. 135: 165-181.

O'Donahue, T. L., J. F. Bishop, B. M. Chronwall, J. Groome, and W. H. Watson III (1984) Characterization and distribution of FMRFamide immunoreactivity in the rat central nervous system. Peptides 5: 563-568.

Rezer, E., and M. Moulins (1983) Expression of the crustacean pyloric pattern generator in the intact animal. J. Comp. Physiol. 153: 17-28.

Robertson, M. R., and M. Moulins (1981a) Oscillatory command input to the motor pattern generators of the crustacean stomatogastric ganglion. I. The pyloric rhythm. J. Comp. Physiol. 143: 453-463.

Robertson, M. R., and M. Moulins (1981b) Oscillatory command input to the motor pattern generators of the crustacean stomatogastric ganglion. II. The gastric rhythm. J. Comp. Physiol. 143: 473-491.

Russell, D. F. (1976) Rhythmic excitatory inputs to the lobster stomatogastric ganglion. Brain Res. 101: 582-588.

Russell, D. F. (1985a) Pattern and reset analysis of the gastric mill rhythm in a spiny lobster, Panulirus interruptus. J. Exp. Biol. 114: 71-98.

Russell, D. F. (1985b) Neural basis of teeth coordination during gastric mill rhythms in spiny lobster, Panulirus interruptus. J. Exp. Biol. 114: 98-119.

Scalise, F. W., B. A. Larson, and S. R. Vigna (1984) Localization of a peptide identified by antibodies to gastrin/CCK in the gut of Cancer magister. Cell Tissue Res. 238: 113-119.

Selverston, A. I., and J. P. Miller (1980) Mechanisms underlying pattern generation in lobster stomatogastric ganglion as determined by selective inactivation of identified neurons. I. Pyloric system. J. Neurophysiol. 44: 1102-1121.

Selverston, A. I., and B. Mulloney (1974) Organization of the stomatogastric ganglion in the spiny lobster. II. Neurons driving the medial tooth. J. Comp. Physiol. 91: 33-51.

Skirboll, L. R., A. A. Grace, D. W. Hommer, J. Rehfeld, M. Goldstein, T. Hökfelt, and B. S. Bunney (1981) Peptide-monoamine coexistence: Studies of the actions of cholecystokinin-like peptide on the electrical activity of midbrain dopamine neurons. Neuroscience 6: 2111-2124.

Smith, G. P., and J. Gibbs (1985) The satiety effect of cholecystokinin: Recent progress and current problems. Ann. NY Acad. Sci. 448:417423.

Trimmer, B. A., L. A. Kobierski, and E. A. Kravitz. (1988) Purification and characterization of FMRFamidelike immunoreactive substances from the lobster nervous system: Isolation and sequence analysis of two closely related peptides. J. Comp. Neurol. 266: 16-26.

Turrigiano, G., and A. I. Selverston (1987) Presence and release of a $\mathrm{CCK}$ /gastrin-like molecule in the lobster stomatogastric ganglion. Soc. Neurosci. Abstr. 13: 1257.

Vigna, S. R. (1985) Cholecystokinin and its receptors in vertebrates and invertebrates. Peptides 6: 283-287. 